2015

\title{
INVESTIGATING THE EFFECTS OF SHORT- AND LONG-TERM CLIMATIC VARIATION ON THE WATER USE OF THREE NORTHERN HARDWOOD TREE SPECIES
}

Alex R. Collins

Michigan Technological University

Follow this and additional works at: https://digitalcommons.mtu.edu/etds

Part of the Botany Commons

Copyright 2015 Alex R. Collins

Recommended Citation

Collins, Alex R., "INVESTIGATING THE EFFECTS OF SHORT- AND LONG-TERM CLIMATIC VARIATION ON THE WATER USE OF THREE NORTHERN HARDWOOD TREE SPECIES", Dissertation, Michigan Technological University, 2015.

https://doi.org/10.37099/mtu.dc.etds/1011

Follow this and additional works at: https://digitalcommons.mtu.edu/etds

Cart of the Botany Commons 
INVESTIGATING THE EFFECTS OF SHORT- AND LONG-TERM CLIMATIC VARIATION ON THE WATER USE OF THREE NORTHERN HARDWOOD TREE SPECIES

\author{
By \\ Alex R. Collins

\begin{abstract}
A DISSERTATION
Submitted in partial fulfillment of the requirements for the degree of DOCTOR OF PHILOSOPHY

In Forest Science
\end{abstract}

MICHIGAN TECHNOLOGICAL UNIVERSITY

2015

(C2015 Alex R. Collins 
This dissertation has been approved in partial fulfillment of the requirements for the Degree of DOCTOR OF PHILOSOPHY in Forest Science.

School of Forest Resources and Environmental Science

Dissertation Advisor: Dr. Molly A. Cavaleri

Committee Member: $\quad$ Dr. Andrew J. Burton

Committee Member: Dr. Thomas G. Pypker

Committee Member: Dr. Veronica L. Webster

School Dean: Dr. Terry Sharik 


\section{Table of Contents}

Preface

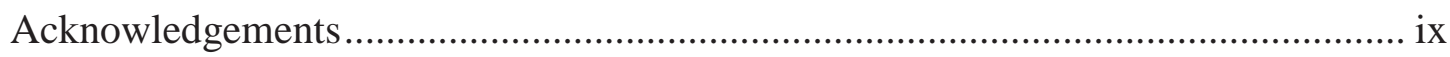

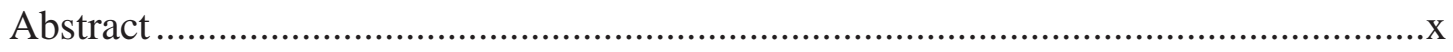

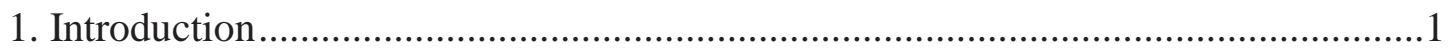

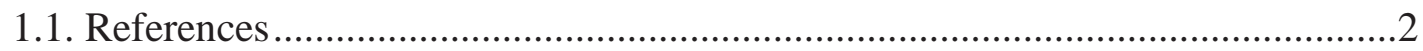

2. Effects of experimental soil warming and water addition on the transpiration of

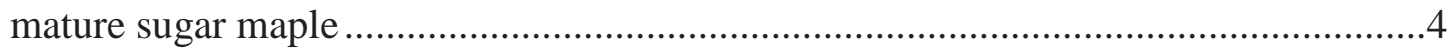

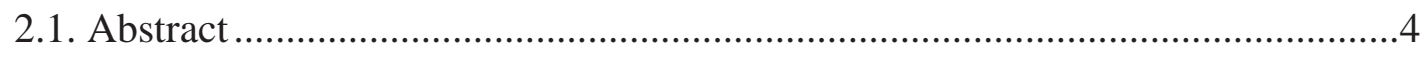

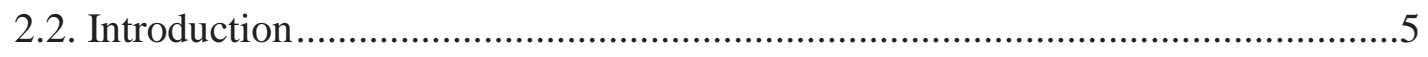

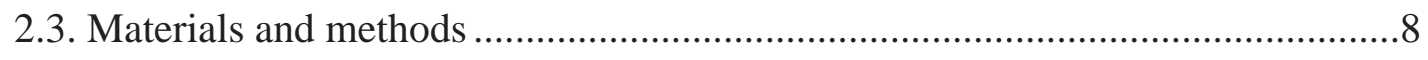

2.3.1. Study site and experimental design..........................................................8

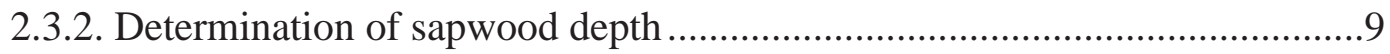

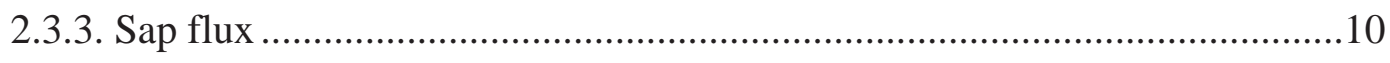

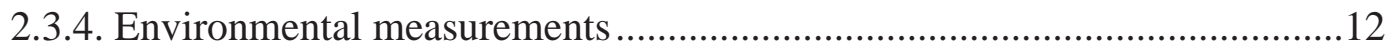

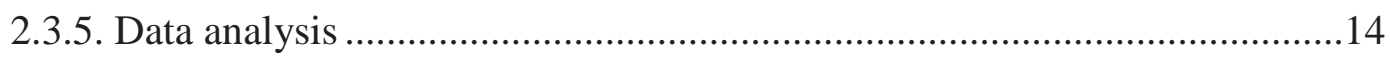

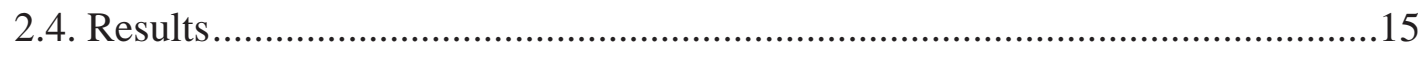

2.4.1. Environmental variables ............................................................................15

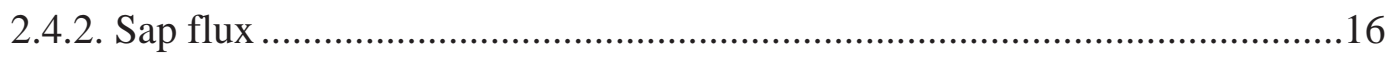

2.4.3. Influence of environmental variables on daily sap flux.................................18

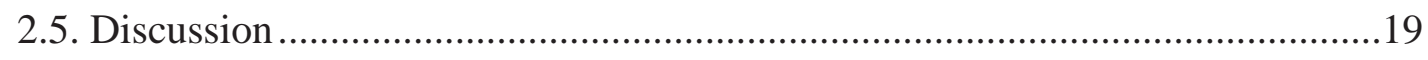

2.5.1. Effects of warming and water addition on transpiration..............................19 
2.5.3. Effects of environmental variables on transpiration ...............................23

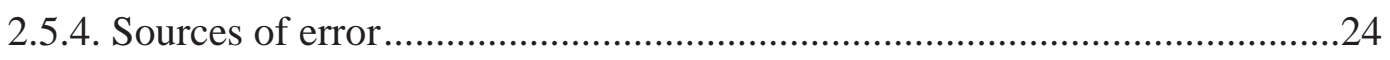

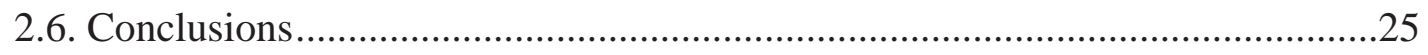

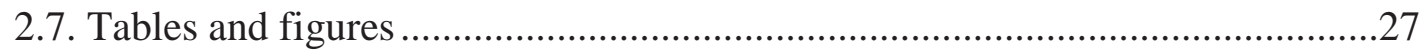

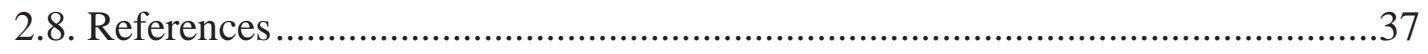

3. The interspecific difference in water use and growth between Populus tremuloides (trembling aspen) and Acer rubrum (red maple) and their respective responses to

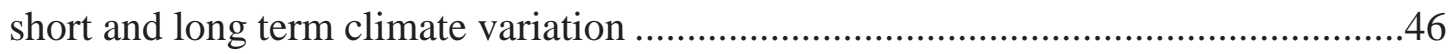

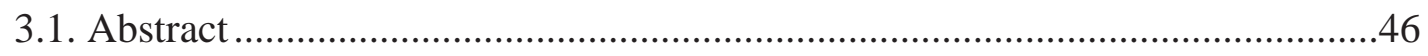

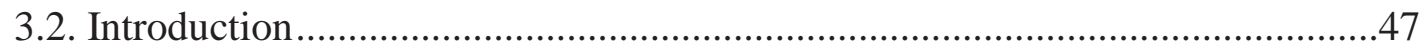

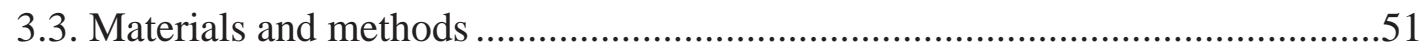

3.3.1. Study site and experimental design ...............................................51

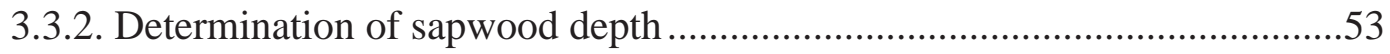

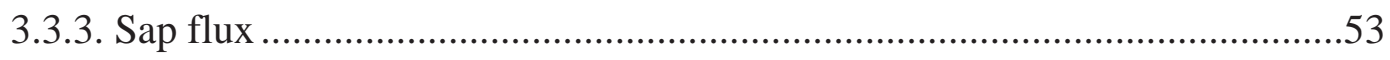

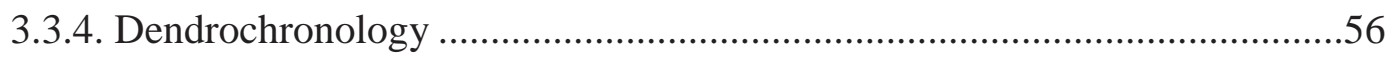

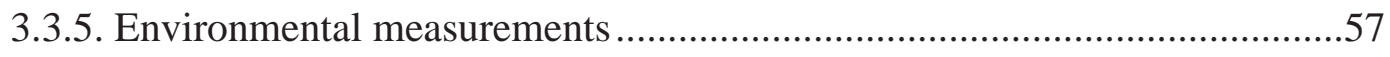

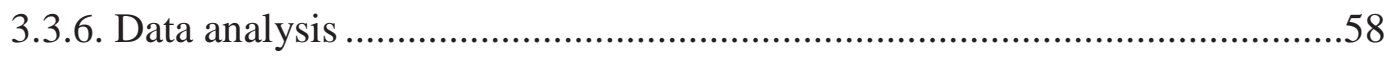

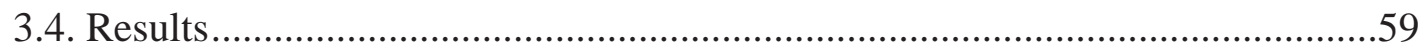

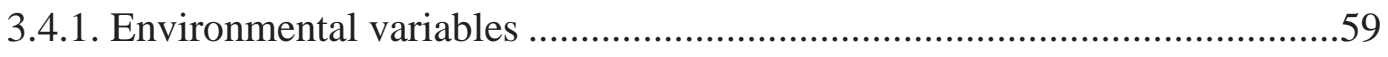

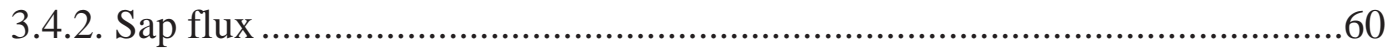

3.4.3. Influence of environmental variables on daily sap flux ..........................61 


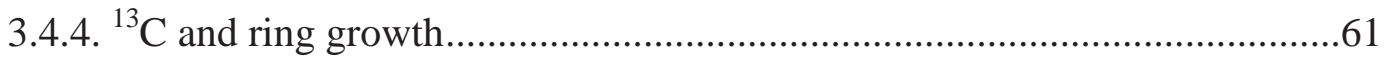

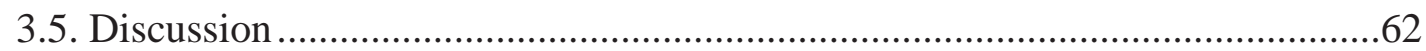

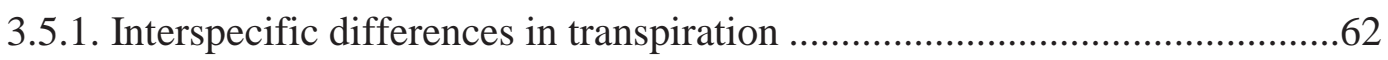

3.5.2. Effects of environmental variables on transpiration .....................................63

3.5.3. Interannual variability and growth .........................................................64

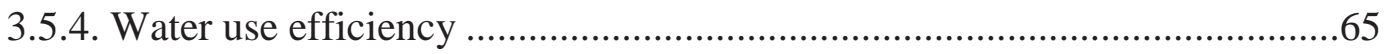

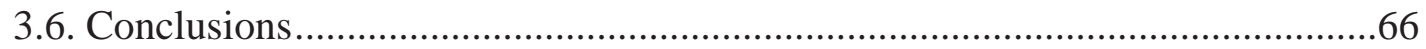

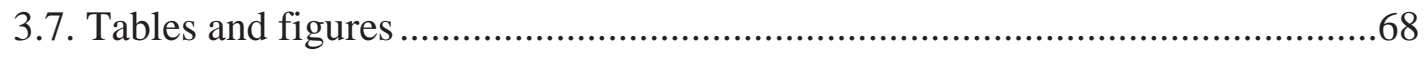

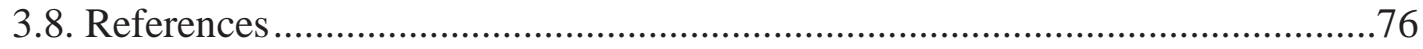

4. Investigating the potential wounding response of two northern hardwood species to long term use of sap flux heat dissipation sensors .....................................................

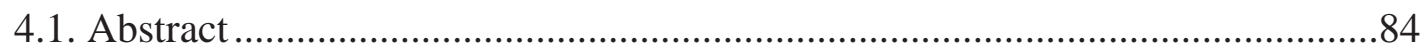

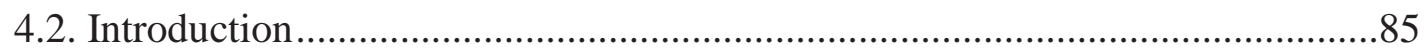

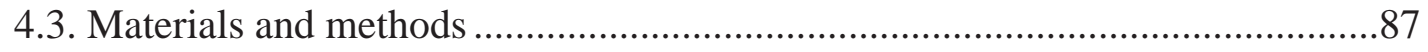

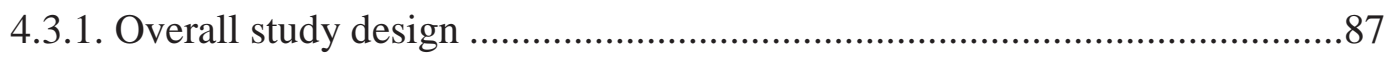

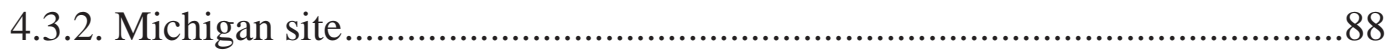

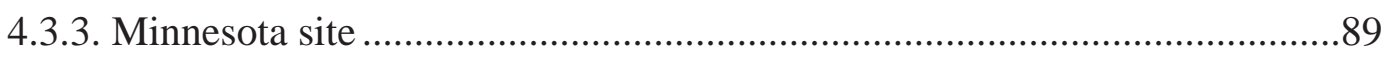

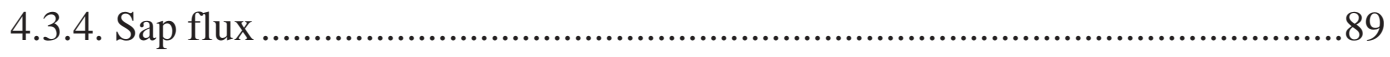

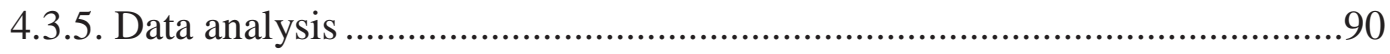

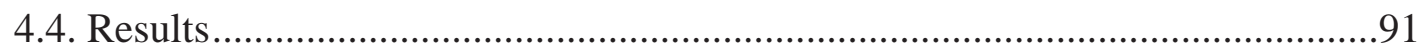

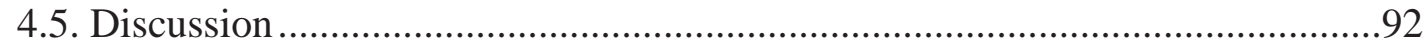

4.5.1. Error due to sensor age for all species .....................................................92 
4.5.2. Timing of sensor error

4.5.3. Wounding response differs across species..........................................93

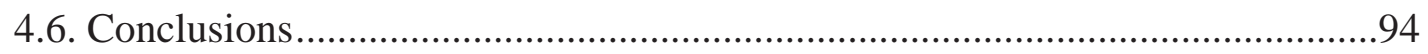

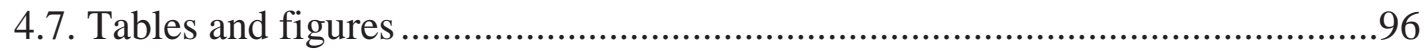

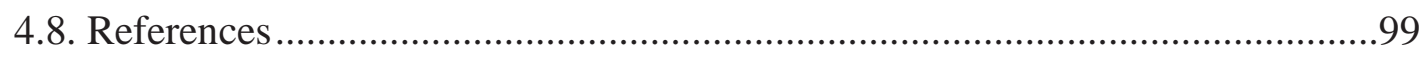

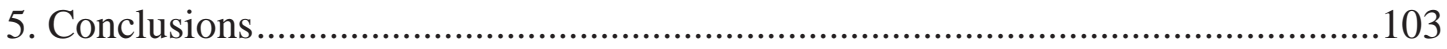




\section{Preface}

Chapter 1 provides a brief introduction to three chapters that are currently in preparation for publication in peer reviewed journals (Chapter 2, 3 and 4). Author contributions for each chapter are listed below. Chapters that are planned to be published are acknowledged in a footnote at the beginning of each chapter.

Chapter 2. Effects of experimental soil warming and water addition on the transpiration of mature sugar maple: in preparation for submission to the peerreviewed journal Tree Physiology. Alex R. Collins conceived and designed the study, collected and analyzed the data, and wrote a majority of the manuscript. Molly A. Cavaleri conceived, designed, and contributed to writing and editing the manuscript. Andrew J. Burton contributed to writing and editing the manuscript.

Chapter 3. The interspecific difference in water use and growth between Populus tremuloides (trembling aspen) and Acer rubrum (red maple) and their respective responses to short and long term climate variation: in preparation for submission to the peer-reviewed journal Tree Physiology. Alex R. Collins conceived and designed the study, collected and analyzed the data, and wrote a majority of the manuscript. Molly A. Cavaleri conceived, designed, and contributed to writing and editing the manuscript.

Chapter 4. Investigating the potential wounding response of two northern hardwood species to long term use of sap flux heat dissipation sensors: in preparation for 
submission to the peer-reviewed journal Tree Physiology. Alex R. Collins conceived and designed the study, collected and analyzed the data, and wrote a majority of the manuscript. Molly A. Cavaleri conceived, designed, and contributed to writing and editing the manuscript. 


\section{Acknowledgements}

I would first and foremost like to thank my advisor Molly Cavaleri. Without her help, guidance, and patience I would not have finished this document. I would also like to thank my committee, Andrew Burton, Tom Pypker and Veronica Webster for their help with researching and writing my dissertation. I would also like to thank Mickey Jarvi, Adam Coble, Michael Stanley, David Kossak, Joe Shannon, and Fahimeh Baziari for their help in the field and lab. I would also like to thank James Vose, Carrie Dorrance, Randy Kolka, and Donna Olsen of the USDA for help with gathering weather data at my Minnesota research site. I also am very grateful for Brian Palik, Deacon Kyllander, and Doug Kastendick of the Marcell Experimental Forest. Without their help I would have been lost in Marcell. I would also like to thank John Bradford of the USDA for initiating my research at Michigan Tech. I would also like to thank the USDA forest service and Michigan Tech's Ecosystem Science Center, Center for Water and Society, and the School of Forestry and Environmental Science for funding my research. I would like to thank my family and friends for supporting me during my studies. Finally, I would like to thank Regina Collins, my mother, for her love, guidance, and support throughout my degree and help in the final edit of this dissertation. 


\begin{abstract}
Many tree species are expected to decline in the northern Midwestern United States due to climate change increasing annual temperature $3-5^{\circ} \mathrm{C}$ by 2100 . Sugar maple (Acer saccharum), an economically important timber and syrup species, is not expected to be sustainable in its current range under projected future climate, while trembling aspen (Populus tremuloides) and red maple (Acer rubrum) are expected to react more favorably to climate change. The success of individual tree species is dependent on how climate change will alter a species environment in regards to water use. Climate change could potentially reduce available soil moisture, reducing potential transpiration within a forest. This dissertation had three objectives; 1) to investigate the effects of experimental soil warming and irrigation on transpiration rates of sugar maple over three growing seasons, 2) to investigate the effects of environmental drivers on water use of trembling aspen and red maple, and to 3) investigate the effects of wounding on the accuracy of sap flux estimates in heat dissipation sensors. Overall, we found that drought effects due to climate change could potentially decrease sugar maple productivity on drier sites within its current range. Further, trembling aspen had higher rates of transpiration, growth and water use efficiency than red maple indicating that trembling aspen may not react as unfavorably to climate change as expected. Finally, we found wounding effects caused an underestimation in sap flux data in sugar maple and trembling aspen when probes remained in trees for two years.
\end{abstract}




\section{Introduction}

The Great Lakes region will likely be subjected to increases in mean annual temperatures along with shifting precipitation patterns in the coming decades (Kirtman et al. 2013). Since the early $20^{\text {th }}$ century, the Upper Midwest has experienced increases of $0.11^{\circ} \mathrm{C}$ and $0.06{ }^{\circ} \mathrm{C}$ per decade in spring and winter temperatures, respectively (Magnuson et al. 1997). Mean annual temperature is expected to further increase 3 to $5^{\circ} \mathrm{C}$ in this region by 2100 (Kunkel 2013, Patricola and Cook 2013), with more frequent and intense heat waves expected (Knapp et al. 2008). This warming trend could increase the number of annual growing degree days, lengthening the growing season and hastening spring snowmelt, which could lead to drier conditions later in the growing season (Barnett et al. 2005). At the same time, modeling suggests that although annual precipitation rates and intensity will increase in the Midwest, this will occur primarily in the winter and fall seasons (Kunkel 2013). On the other end of the precipitation spectrum, droughts are also likely to become more frequent and intense for the Midwestern U.S. in the the coming decades (Knapp et al. 2008). Thus, even though overall annual and winter precipitation may increase, late summer available water may become scarce as a result of warmer conditions across the Great Lakes region, and both temperature and precipitation will likely exhibit more frequent extreme events. Alterations in weather patterns will likely effect tree physiology for a variety of species across the Midwestern United States. Understanding short- and long-term effects of climate on 
water use of hardwood species will aid in better understanding how climate change will affect the Midwestern United States tree speces.

\subsection{References}

Barnett, T. P., J. C. Adam, and D. P. Lettenmaier. 2005. Potential impacts of a warming climate on water availability in snow-dominated regions. Nature 438:303-309.

Kirtman, B., S. B. Power, J. A. Adedoyin, G. J. Boer, R. Bojariu, I. Camilloni, F. J. Doblas-Reyes, A. M. Fiore, M. Kimoto, G. A. Meehl, M. Prather, A. Sarr, C. Schär, R. Sutton, G. J. van Oldenborgh, G. Vecchi, and W. H.J. 2013. Nearterm Climate Change: Projections and Predictability. Pages 953-1028 in T. F. Stocker, D. Qin, G.-K. Plattner, M. Tignor, S. K. Allen, J. Boschung, A. Nauels, Y. Xia, V. Bex, and P. M. Midgley, editors. Climate Change 2013: The Physical Science Basis. Contribution of Working Group I to the Fifth Assessment Report of the Intergovernmental Panel on Climate Change. Cambridge University Press, Cambridge, United Kingdom and New York, NY, USA.

Knapp, A., C. Beier, D. Briske, A. Classen, and Y. Luo. 2008. Consequences of More Extreme Precipitation Regimes for Terrestrial Ecosystems. BioScience 58:811-821. 
Kunkel, K. E., L.E. Stevens, S.E. Stevens, L. Sun, E. Janssen, D. Wuebbles, S.D. Hilberg, M.S. Timlin, L. Stoecker, N.E. Westcott, and J.G. Dobson. 2013. Part 3. Climate of the Midwest U.S. Page 96 NOAA Technical Report NESDIS $142-3$.

Magnuson, J. J., K. E. Webster, R. A. Assel, C. J. Bowser, P. J. Dillon, J. G. Eaton, H. E. Evans, E. J. Fee, R. I. Hall, L. R. Mortsch, D. W. Schindler, and F. H. Quinn. 1997. Potential effects of climate changes on aquatic systems: Laurentian Great Lakes and Precambrian Shield Region. Hydrological Processes 11:825-871.

Patricola, C. and K. Cook. 2013. Mid-twenty-first century warm season climate change in the Central United States. Part I: regional and global model predictions. Climate dynamics 40:551-568. 


\section{Effects of experimental soil warming and water addition on the transpiration of mature sugar maple ${ }^{1}$}

\subsection{Abstract}

Sugar maple (Acer saccharum), an economically important timber and syrup species, is not expected to react favorably under projected future climates, which include an increase of $3-5^{\circ} \mathrm{C}$ in the Upper Midwestern USA by 2100 . The objective of our study was to investigate the effects of experimental soil warming and water addition on transpiration rates of sugar maple over three growing seasons. We installed heat dissipation sap flow sensors in 33 trees in eight $100 \mathrm{~m}^{2}$ plots; two replicates each of four treatments: 1) heat-only, 2) water-only, 3) heat+water, and 4) control. As expected, sugar maple transpiration decreased when exposed to the heat-only treatment in all years, yet transpiration rates were no different relative to the control under the combination heat+water treatment in year 1, indicating that the supplemental water compensated for the warming-induced soil evaporation. Thus, the reduction due to warming was apparently the result of an indirect effect of warming on soil moisture rather than a direct effect of warming on the process of transpiration. Solar radiation explained more of the variability in daily transpiration rates than either soil moisture or vapor pressure deficit, even though solar radiation was not experimentally altered by this study. Overall, our results suggest drought

\footnotetext{
${ }^{1}$ This chapter is in preparation for submission to the peer-reviewed journal Tree Physiology.
} 
effects due to climate change could potentially decrease sugar maple productivity on drier sites within its current range.

\subsection{Introduction}

Atmospheric warming due to climate change could have both direct and indirect effects on tree water use, and thus the water cycling of forest ecosystems. An example of a potential direct effect on transpiration rates could include a stomatal response to atmospheric changes in leaf to air vapor pressure deficit (VPD) as a result of increased air temperature. Under ambient conditions, mid-day depression in transpiration has been found in various forest canopies as a result of stomatal closure during the hottest part of the day, corresponding to the greatest VPD (Gao et al. 2002, Zhang et al. 2005), and this pattern may be exacerbated under continued warming. Warming could also directly affect transpiration rates as a result of longer-term impacts on root dynamics. For example, decreased root biomass has been found as a result of long term soil warming (Melillo et al. 2011), which could reduce overall absorption, leading to a reduction in forest transpiration rates. The primary indirect effect of warming on tree water use is the result of reductions in soil moisture availability. Under the soil warming treatments of our study site within a sugar maple forest, evaporation from the soil surface decreased water availability in the upper soil layers (Jarvi and Burton 2013). This could induce water stress in trees, leading to stomatal closure and decreased transpiration (Ni and Pallardy 1991, Zhao et al. 2013). Ecosystem warming experiments have been used to investigate ecohydrological 
effects of increased temperature on tree species (Rustad et al. 2001, Rustad 2008), yet no study has yet been able to experimentally tease apart the indirect and direct effects of soil warming in a mature forest.

Sugar maple (Acer saccharum) is a very important species in the upper Midwestern United States, representing 12 million hectares (Horsley et al. 2002). The economy of maple syrup production alone includes 10 million trees and an estimated total annual revenue of $\sim \$ 130$ million (Horsley et al. 2002, Farrell and Stedman 2013, USDA 2014). Sugar maple, which ranges from north-eastern and mid-western United States northward to south-eastern Canada (Horsley et al. 2002), is expected to react unfavorably to projected future climate scenarios compared to many co-occurring tree species (Whitney and Upmeyer 2004, Prasad et al. 2014), and there is already evidence of decline of this valuable species (Bal et al. 2015). Sugar maples are generally found in moist environments and have shallow rooting systems, which can limit water absorption during dry conditions (Hinckley et al. 1979, Godman et al. 1990). Historically, decreased soil water availability has been a likely contributor to periodic sugar maple mortality episodes during the early twentieth century (Millers et al. 1989, Houston 1998, McDowell 2011). Part of the overall decline in sugar maple includes the occurrence of dieback, the continual death of exterior branches and leaves, which is increasing across the American Upper Midwest (Frey et al. 2004, Auclair et al. 2010). While the primary drivers of these phenomena are poorly understood, recent evidence shows correlations between higher incidences of maple dieback and earthworm invasion, with a proposed mechanism 
pointing to the resulting decreased water-holding capacity of soil due to thinning of the protective litter layer (Bal et al. 2015). Abnormal precipitation patterns, drought, and extreme temperature events could increase dieback in sugar maple (Frey et al. 2004), which ultimately could affect timber and/or syrup production of this economically important species.

We investigated the effects of experimental soil warming and moisture addition on transpiration rates of sugar maple in a mature northern hardwood forest in the Upper Peninsula of Michigan. To date, this experiment represents the only fully factorial in situ warming $\times$ water addition experiment in any mature forest (Jarvi and Burton 2013). Our study design enables us to separate the direct effects of increasing temperature from the indirect effects of decreasing soil moisture on transpiration of sugar maple. We hypothesized that: 1) warming-only treatments would decrease transpiration rates, while water-only treatments would increase transpiration rates, both as a result of indirect treatment effects on soil moisture; 2 ) in the combined warming + water treatment, the water addition would compensate for negative effects of warming on sugar maple transpiration; 3) a greater negative effect of the warmingonly treatment on transpiration would occur during drier years of study; and 4) soil moisture would be a stronger driver of transpiration than either canopy VPD or solar radiation, because of sugar maple's tendency to favor moist soil conditions. 


\subsection{Materials and Methods}

\subsubsection{Study site and experimental design}

The sugar maple dominated stand selected for the study was located $13 \mathrm{~km}$ south of L'Anse, Michigan within the Ford Center and Forest of Michigan Technological University $\left(46^{\circ} 64^{\prime}\right.$ N, $\left.88^{\circ} 48^{\prime} \mathrm{W}\right)$. Sugar maple accounted for $89.3 \%$ $\left(21.7 \mathrm{~m}^{2} \mathrm{ha}^{-1}\right)$ of the overstory basal area, with dominant trees 100 years in age or more. American elm (Ulmus Americana L.), eastern hemlock (Tsuga canadensis L.), ironwood (Ostrya Virginia Mill.), and yellow birch (Betula alleghaniensis Britton) also occurred within the overstory. The mean annual temperature of the study site was $4.9{ }^{\circ} \mathrm{C}$, with an average $879 \mathrm{~mm}$ of annual precipitation, and the soil was classified as Kallio silt loam (Jarvi and Burton 2013). Additional information on site history can be found in Jarvi and Burton (2013).

The overall study used three blocks of four treatments: heat, heat+water, water, and control, each assigned to three replicate $10 \mathrm{~m}$ x $10 \mathrm{~m}$ plots with $5 \mathrm{~m}$ wide buffers. The heat-only treatment was continuously warmed with sixteen $1.65 \mathrm{~m}$ long infrared heaters positioned in four rows of four lamps each, spaced $2.5 \mathrm{~m}$ apart and $1.5 \mathrm{~m}$ from the ground (1500 Watt, MRM-1215, Kalglo Electronics Company, Inc., Bethlehem, PA). The suspended heaters increased soil temperature 4 to $5^{\circ} \mathrm{C}$ above ambient, down to at least $30 \mathrm{~cm}$ in depth. The heat+water treatment was identical to the heat treatment, but with supplemental irrigation at a rate equivalent to $+30 \%$ of average annual growing season precipitation, to compensate for evaporative losses 
due to the warming treatment. The water-only treatment had the same rate of water addition as the heat+water treatment, but no heating infrastructure. Water used for both heat+water and water-only treatments was collected with three 1,900 L tanks attached to the rain gutter system of a nearby building and added following natural precipitation events via four sprinkler heads located at all corners of each irrigated plot (5000 series rotor, Rain Bird Corporation, Tucson, AZ). The control treatment had no infrastructure and experienced ambient temperature and precipitation.

\subsubsection{Determination of sapwood depth}

Sapwood thickness of instrumented trees was determined using an allometric relationship between diameter at breast height $(\mathrm{DBH})$ and sapwood thickness developed from a sampling of 20 sugar maple trees located outside of the experimental plots, but within 50 meters of the study area. Trees ranging from 9-45 cm DBH were cored at breast height in April of 2011 using a stainless steel increment borer (18”, 5 mm, Haglof Company Group, Sweden). The sample trees were selected by generating 20 random numbers between 0 and 50 without resampling to determine points along a $50 \mathrm{~m}$ transect. The nearest tree to each randomly selected point along the transect was cored. Cores were placed in a chilled light-proof container of tetrazolium (TTZ) vital stain for 48 hours (Sigma-Aldrich, St. Louis, MO). The TTZ stained the living cells of the sapwood pink, and dyed cores were measured for sapwood thickness to the nearest mm using a ruler and a $10 \mathrm{X}$ dissection microscope (SZ, Olympus Optical Co., Tokyo, Japan). Cores were shaved with a razor blade to 
make dyed cells clearly visible. The linear regression relationship between DBH and sapwood depth was then used to estimate sapwood depth of trees on study plots, based on their DBH.

\subsubsection{Sap flux}

Xylem sap flux was measured in two of the three replicate blocks ( 8 plots total) on 33 sugar maple trees (7-9 sugar maple trees per treatment), ranging from 8$52 \mathrm{~cm} \mathrm{DBH}$. Sap flux measurements were continuous from mid-May to midOctober, in 2011, 2012, and 2013. Sap flux density was measured with variablelength heat dissipation sap flux sensors based on the design of Granier $(1985,1987)$ and modified by James et al. (2002). Sensors consisted of two probes, each with a 1 $\mathrm{cm}$ long aluminum tip containing a copper-constantan thermocouple junction. Each upper (downstream) probe was heated with a coil of nichrome wire, yielding a resistance of approximately $100 \mathrm{ohms}$ per sensor. Pairs of probes were installed 10 $\mathrm{cm}$ apart vertically, and at several depths per tree, to account for radial variability in sap flux with sapwood depth (Gebauer et al. 2008). For trees 8-10 cm DBH, sensors were inserted into the sapwood at depths of 1,2 , and $3 \mathrm{~cm}$, and for trees $>10 \mathrm{~cm}$ $\mathrm{DBH}$, sensors were inserted at 1, 3, and $5 \mathrm{~cm}$ depths. The three sap flux sensors per tree were staggered vertically near breast height, and at least $20 \mathrm{~cm}$ apart horizontally to prevent heating overlap. Reflective insulation (Reflectix, Inc., Markleville, IN) was wrapped around each instrumented tree to prevent an external thermal gradient (Lu et al. 2004). Four deep-cycle batteries (12 V, 105 AH; model M2 and M3 Diehard, Sears, Hoffman Estates, IL) supplied power through a voltage regulating station to 
heat the upper (heated) probes. Batteries were constantly charged by an alternating current source within site, and voltage was individually set for each sensor to yield an output of $0.15 \mathrm{~W}$ per heated probe. The temperature difference, determined from the voltage differential between the two thermocouple tips in the heated and unheated probes, was measured every minute, and the average was logged every 10 minutes with a CR1000 datalogger and two 32 channel relay multiplexers (Campbell Scientific, Logan, UT). Sensors found to be faulty were replaced as needed.

Temperature differences between probes in each sensor were converted to sap flux densities $\left(v ; \mathrm{g} \mathrm{m}^{-2} \mathrm{~s}^{-1}\right)$ based on Granier's empirical calibration method (Granier 1987, Gebauer et al. 2008):

$$
v=119 \times\left(\frac{\Delta V_{m}-\Delta V}{\Delta V}\right)^{1.231}
$$

where $\Delta V$ is the difference in voltage between the two thermocouples for each 10 minute interval, and $\Delta V_{\mathrm{m}}$ is the daily maximum difference in voltage, corresponding to minimum daily sap flux density. Sap flux was scaled up to whole tree sap flux $(Q$, g tree $\mathrm{s}^{-1}$ ) by summing sap flux densities across all annuli of sapwood for each tree:

$$
Q=\sum_{i=1}^{n} \pi\left(r_{i}^{2}-r_{i-1}^{2}\right) v_{i}
$$

where $r_{i}$ was the exterior radius $(\mathrm{cm}), r_{i-1}$ was the interior radius $(\mathrm{cm})$, and $v_{i}$ was the sap flux density $\left(\mathrm{g} \mathrm{m}^{-2} \mathrm{~s}^{-1}\right)$ of the $i^{\text {th }}$ annuli (Kagawa et al. 2009). Sap flux per unit sapwood area for each tree $\left(Q_{s} ; \mathrm{g} \mathrm{m}_{\mathrm{sw}}^{-2} \mathrm{~s}^{-1}\right)$ was determined by dividing whole tree sap flux $(Q)$ by the sapwood area of each tree calculated using DBH allometries described above. Daily sap flux per tree $\left(J ; \mathrm{kg} \operatorname{tree}^{-1}\right.$ day $\left.^{-1}\right)$ was calculated by summing the ten minute intervals of $Q$ for each 24 hour period. Daily sap flux per 
unit sapwood area $\left(J_{s} ; \mathrm{kg} \mathrm{m}^{-2}\right.$ sapwood day $\left.{ }^{-1}\right)$ for each tree was calculated by dividing whole tree rates $(J)$ by total sapwood area per tree. Finally, plot level transpiration $\left(E_{c}, \mathrm{~mm} \mathrm{day}^{-1}\right)$ was calculated using the following equation (Tang et al. 2006):

$$
E_{C}=J * \frac{A_{s}}{A_{g}}
$$

where $A_{s}$ was the total sapwood area $\left(\mathrm{m}^{2}\right)$ of the study plots, estimated from total basal area of the stand, and $\mathrm{A}_{\mathrm{g}}$ was the total area of the plots $\left(\mathrm{m}^{2}\right)$.

A linear relationship between sap flux density and sapwood depth was used to gap-fill missing data due to sensor failure and to estimate sap flux rates of unmeasured sapwood annuli for all trees. In order to gap-fill missing daily data $\left(J_{s}\right)$, a multiple regression model was developed with $J_{s}$ as the dependent variable and daily values of soil temperature, volumetric soil moisture, canopy air temperature, canopy VPD, photosynthetically active photon flux density (PPFD), and ambient precipitation as the independent variables. A backward elimination model selection procedure was used to find the best fit model for prediction of $J_{s}$. Daily $J_{s}$ values were then calculated based on the best-fit model and environmental conditions of the missing day.

\subsubsection{Environmental measurements}

Mean daytime soil temperature $\left({ }^{\circ} \mathrm{C}\right)$, volumetric soil moisture $\left(\mathrm{cm}^{3} \mathrm{~cm}^{-3}\right)$, canopy air temperature $\left({ }^{\circ} \mathrm{C}\right)$, canopy VPD $(\mathrm{kPa})$ integrated photosynthetically active photon flux density $\left(\mathrm{PPFD}_{\text {int }}\right.$; mol $\mathrm{m}^{-2}$ day $\left.^{-1}\right)$, and ambient total daily precipitation 
$(\mathrm{mm})$ were measured within or near the study site. Soil temperature and soil moisture were measured at depths up to $10 \mathrm{~cm}$ below and between heater lines (Hobo U12 4external channel outdoor/ industrial data logger with TMC6-HA probes, Onset Computer Corporation, Bourne, MA; Em50 data loggers with 5TM temperature/moisture probes, Decagon Devices Inc., Pullman, Washington). Additional measurements were made at 20 and $30 \mathrm{~cm}$ to confirm depth of heat distribution for several months. Air temperature and relative humidity were measured at 3,8 and $12 \mathrm{~m}$ above the soil surface in one plot of each treatment (HOBO U23 Pro v2 temperature/relative humidity data logger with RS1 solar radiation shield, Onset Computer Corporation, Bourne, MA). Mean daytime VPD was calculated using the following equation (Campbell and Norman 1998):

$$
\mathrm{VPD}=(a \exp (b \mathrm{~T} / \mathrm{T}+c)) *\left(1-h_{r}\right)
$$

Where the environmental constants were $a=0.611 \mathrm{kPa}, b=17.502$, and $c=240.97^{\circ}$ $\mathrm{C}$, while $\mathrm{T}$ was air temperature $\left({ }^{\circ} \mathrm{C}\right)$ and $h_{r}=$ relative humidity $(\%)$. PPFD int was measured $3 \mathrm{~m}$ above the soil surface in an open field approximately $500 \mathrm{~m}$ away from the plots to ensure there was no shading due to buildings or trees [Hobo photosynthetically active radiation (PAR) smart sensor with Micro station data logger, Onset Computer Corporation, Bourne, MA]. Ambient precipitation was measured using a weighing rain gauge (Model 5-780, Belfort Instrument Co., Baltimore, MD) in an open field approximately $200 \mathrm{~m}$ away from the plots.

Daily mean values were calculated for soil temperature, canopy temperature, and VPD from 10 minute values over daylight hours only ( between 0600-2100 hrs). 
Daily mean soil moisture was averaged over 24 hour periods (between 0000-2400 hrs) to calculate mean daily values. Total daily ambient precipitation data was summed for each day. PPFD 10 minute values were summed over the course of daylight hours to calculate total daytime integrated light ( $\left.\mathrm{PPFD}_{\text {int }}\right)$.

\subsubsection{Data analysis}

Linear regressions were used to determine relationships between sapwood depth and DBH and between sap flux density $(v)$ and sapwood depth. Analysis of variance (ANOVA) was used to compare interannual differences in daytime VPD and daytime air temperature on the site. Two-factor repeated measures ANOVA was used to determine treatment effects of soil warming and water addition within and across years for the daily values of $J_{s}, E_{c}$, daytime soil temperature, and soil moisture. Analyses of covariance (ANCOVAs) were used to assess the relationships between $E_{c}$ and covariates soil moisture, VPD, soil temperature and daily integrated light $\left(\mathrm{PPFD}_{\mathrm{int}}\right)$ across each treatment. A partial regression analysis was also used to determine the relative importance of daily $\mathrm{PPFD}_{\mathrm{int}}, \mathrm{VPD}$, and soil moisture and temperature on mean daily $E_{c}$ (pooling across treatments) by removing each variable, one at a time, from the model and comparing $R^{2}$ values to the full model $R^{2}$ to determine how much variability was accounted for by each environmental driver. Data analyses were performed with the statistical package $R$ (R Core Team 2014). 


\subsection{Results}

\subsubsection{Environmental variables}

Daily values of both soil temperature and moisture were compared across treatments within years, and within treatments across years. Soil temperatures in the heat-only and heat+water treatments were greater than both unheated treatments, but not significantly different from each other (Figure 1a). Control and water-only treatments did not differ in soil temperature within years (Figure 1a). Soil temperatures in heated treatments decreased each successive year, while soil temperatures in unheated treatments were no different between years (Figure 1a). Volumetric soil moisture in the heat-only treatment was significantly lower than the control in all years, while soil moisture in the water-only treatment was greater than control in 2011 and 2012, but not in 2013 (Figure 1b). In 2011 and 2012, soil moisture in the heat+water treatment was no different than in the control plots, but the combined treatment showed lower soil moisture than control plots in 2013 (Figure 1b). Soil moisture in all treatments increased each successive year of study (Figure 1b).

Daily values of vapor pressure deficit (VPD) and air temperature were compared between treatments at various heights within the canopy. Neither withincanopy VPD nor air temperatures were significantly different among 3,8 and $12 \mathrm{~m}$ heights measured within treatments ( $P=0.96$ and 0.60 respectively; data not shown). Additionally, there were no differences among treatments in mean canopy 
temperature or VPD $(P=0.57$ and 0.64 , respectively, data not shown), indicating that the warming treatments warmed and dried the soil but neither temperature nor humidity were affected by treatment in the air above the heating lamps. Mean daytime canopy temperatures did not differ across treatments or years (Figure 2a), while mean daytime VPD was significantly lower in 2013 compared to 2011 and 2012 (Figure 2b). Daily total integrated values were summed to estimate monthly total integrated light and precipitation (Figure 3). Integrated light was similar across all years of study in the month of August, while 2012 showed the highest levels of light in the study in the month of July. It was not possible to compare June data across years due to instrument failure (Figure 3a), and the second and third years of study had higher rates of precipitation during July than the first year (Figure 3b).

\subsubsection{Sap flux}

Sugar maple sapwood thickness was linearly correlated with DBH $(P=0.001$, $\mathrm{r}^{2}=.84$, data not shown):

Sapwood thickness $=0.2245 * \mathrm{DBH}+1.5982$

This relationship was used to estimate sapwood depth for probe placement and sapwood area measurements for scaling purposes. Sap flux density decreased slightly with sapwood depth (Figure 4), and we used this relationship to gap-fill missing data and to estimate rates of unmeasured annuli. Approximately, 39\% of sap flux density data was gap-filled using the relationship in Figure 4. The best-fit model for $\mathrm{J}_{\mathrm{s}}$ (daily total sapflux per sapwood area for each tree) after backward elimination procedures was found to be the following: 


$$
\mathrm{J}_{\mathrm{s}}=-33.5+\left(482.5 * \mathrm{M}_{\mathrm{s}}\right)+0.003214 * \mathrm{PPFD}_{\mathrm{int}}+\left(5.784 * \mathrm{~T}_{\mathrm{c}}\right) \quad \text { Eq. } 6
$$

Where $M_{s}$ is mean daily soil moisture, $P P F D_{\text {int }}$ is total daily integrated light, and $T_{c}$ is mean daily canopy temperature $\left(P=0.001, \mathrm{r}^{2}=.76\right)$. Approximately, $33 \%$ of $\mathrm{J}_{\mathrm{s}}$ values were gap-filled using the above model.

Mean instantaneous sap flux per unit sapwood area $\left(Q_{s}\right)$ was measured within treatments across all years of study. Peak rates of $\mathrm{Q}_{\mathrm{s}}$ occurred around approximately 15:00 hours across all years of study within all treatments (Figure 5). Q $\mathrm{Q}_{\mathrm{s}}$ decreased under heat-only treatments in all years of study, when compared to the control (Figure 5). $Q_{s}$ was greater than the control in the water-only treatment in both 2011 and 2012, but showed the opposite trend in 2013 (Figure 5). The combined heat+water treatment had similar rates of $\mathrm{Q}_{\mathrm{s}}$ compared to the control in 2011, but had lower rates than trees in control plots in the other two years of study (Figure 5).

Total daily sap flux per unit sapwood area $\left(\mathrm{J}_{\mathrm{s}}\right)$ and plot level transpiration $\left(\mathrm{E}_{\mathrm{c}}\right)$ were measured within each treatment across all years of study. The heat-only treatment significantly decreased $\mathrm{J}_{\mathrm{s}}$ and $\mathrm{E}_{\mathrm{c}}$ in all years of study (Figure 6). The wateronly treatment significantly increased $\mathrm{J}_{\mathrm{s}}$ and $\mathrm{E}_{\mathrm{c}}$ compared to the control in 2011 and 2012, but both $\mathrm{J}_{\mathrm{s}}$ and $\mathrm{E}_{\mathrm{c}}$ in the water-only treatment were lower than control plots in 2013 (Figure 6). Three of nine trees in the water-only treatment were excluded from data analysis in 2013 as a result of sensor malfunction, which may partially explain the unexpected results. In the combined heat + water treatment, $\mathrm{J}_{\mathrm{s}}$ was no different than the control in 2011, but in subsequent years, $\mathrm{J}_{\mathrm{s}}$ was decreased compared to 
control (Figure 6a). $\mathrm{E}_{\mathrm{c}}$ of the heat + water treatment, in contrast, was no different from the control in all three years (Figure 6b).

Overall trends of $\mathrm{J}_{\mathrm{s}}$ and $\mathrm{E}_{\mathrm{c}}$ were compared by each year of study. Both $\mathrm{J}_{\mathrm{s}}$ and $E_{c}$ increased every successive year of study in the control treatment (Figure 6). $J_{s}$ in the heating-only treatment increased every year of study, but $\mathrm{E}_{\mathrm{c}}$ showed no difference between 2012 and 2013 (Figure 6). $\mathrm{J}_{\mathrm{s}}$ and $\mathrm{E}_{\mathrm{c}}$ in the water-only treatment increased in 2012 compared to 2011; however $\mathrm{J}_{\mathrm{s}} 2013$ data was no different from either 2012 or 2011 (Figure 6). Water-only $\mathrm{E}_{\mathrm{c}}$ in 2013 was only similar to 2011 water-only data (Figure $6 b$ ). $\mathrm{J}_{\mathrm{s}}$ and $\mathrm{E}_{\mathrm{c}}$ in the heat+water treatment increased in 2013 compared to 2011 and 2012, which were not significantly different from each other (Figure 6).

\subsubsection{Influence of environmental variables on daily sap flux}

Environmental variables were compared with stand transpiration across all years of study. In addition to a clear treatment effect in all cases, results from the ANCOVAs indicated that PPFD $_{\text {int }}$, soil moisture, VPD, and soil temperature were all significant predictors of $\mathrm{E}_{\mathrm{c}}$, and all covariates showed interactions with treatment except VPD (Tables 1 and 3 and Figure 7). Partial regression analysis found that total integrated PPFD explained the most variability in $\mathrm{E}_{\mathrm{c}}$ (data pooled across treatments), followed by daytime VPD, soil temperature and soil moisture (Table 2). The line separation among treatments for the relationships between $E_{c}$ and $\mathrm{PPFD}_{\text {int, }} \mathrm{VPD}$, and soil temperature were similar to that of treatment differences in soil moisture levels (Figure 1b), where the steepest slopes and/or greatest intercepts were for water-only treatments, the shallowest slopes and/or lowest intercepts were for heat-only 
treatments, and both control and heat + water showed intermediate slopes and intercepts (Table 3 and Figures 7a, c, and d). A clear pattern was less apparent in the variation among treatments for the relationship between $E_{c}$ and soil moisture.

\subsection{Discussion}

2.5.1. Effects of warming and water addition on transpiration

Overall, the trees in our study were transpiring in the range of $3-5 \mathrm{~mm} \mathrm{day}^{-1}$ at the stand level. These values were within the range of other Upper Midwestern broadleaved forests in the United States, including another sugar maple forest (1-4 $\mathrm{mm} \mathrm{day}^{-1}$; (Ewers et al. 2008) and a mature poplar stand (2-3 $\mathrm{mm} \mathrm{day}^{-1}$; (Schmidt et al. 2014). Our data supported our first and second hypotheses that sugar maple transpiration would be indirectly affected by the heat-only treatment due to a reduction of soil moisture caused by increased soil evaporation. Mean daily sap flux per unit sapwood area $\left(J_{s}\right)$ and plot level transpiration $\left(E_{c}\right)$ rates were lower in the heat-only treatment than that of the control across all years, yet the supplemental irrigation in the heat + water treatment appeared to mitigate these negative effects of warming, at least in the first year (2011) of the experiment (Figures 5 and 6). The purpose of the heat + water treatment was to isolate the effects of temperature alone, without the concomitant effects of decreasing soil moisture. In 2012 and 2013, however, it appears that the water addition was not sufficient to counteract the 
detrimental effects of warming, possibly because water was not as limiting in these two years compared to 2011 (Figure 3b).

Experimental warming through various methods generally reduces water availability via increased soil evaporation (Norby and Luo 2004), and we found soil moisture levels were lower than the control in the heat-only treatment across all years of the study (Figure 1b). Similarly, open top chamber warming studies found a decrease in soil moisture compared to ambient temperature treatments (Gunderson et al. 2000, Dermody et al. 2007). A combination of low available soil water and brief, extreme spikes in air temperatures have been found to reduce sugar maple water use of saplings (Ellsworth and Reich 1992, Filewod and Thomas 2014), and others have reported that low soil moisture may have decreased the sap flux of black spruce (Bovard et al. 2005, van Herk et al. 2011). Additionally, xylem sap flux decreased linearly with decreasing soil moisture in four out of five broad leaved temperate tree species investigated under varying ambient soil moisture conditions in Germany (Holscher et al. 2005). Another study in Lower Michigan found red maple (Acer rubrum) stomatal behavior to be especially sensitive to declines in soil moisture (Bovard et al. 2005). Studies on upland oak, beech, and Scots pine suggested that a decrease in soil moisture decreased canopy transpiration (Poyatos et al. 2005, Wullschleger and Hanson 2006, Betsch et al. 2011). The reduction in soil moisture in our heat-only treatment likely caused the indirect effects absorption and sap flux rates. 
Soil moisture reductions and/or warming may also have direct effects on root longevity, potentially exacerbating a reduction in transpiration in the heating-only treatment. This would be similar to a study which found a reduction in oak root biomass in the upper soil when exposed to drought and air warming (Kuster et al. 2013). Experimental soil warming studies in mature forests have found reductions in fine root biomass (Melillo et al. 2011) and total root standing crop (Zhou et al. 2011) after several years of warming, which could have implications on tree and forest-level water use, and potentially a decrease in soil carbon storage (Melillo et al. 2011). However, we have not found any evidence in this study of reduced root biomass as a direct result of warming for three years (Jarvi and Burton 2013), so root death is not likely to be the reason behind our observed reduction in transpiration with warming. However, we did fine a reduction in root respiration with decreasing soil moisture (Jarvi and Burton 2013). We did also find evidence of reduced mycorrhizal biomass (Kratz 2013), which also has the potential to affect stand-level exploitation of soil resources, including soil moisture. Additionally, the presence of a fragipan on the site further limited water sources within the soil horizon. Soil depth would need to be considered in regards to moisture availability and drought tolerance if climate change were to move the sugar maple range northward.

The hypothesis that sugar maple transpiration should increase with water-only treatments was supported, but only in the first two years of study (Figure 6). Similarly, a Chinese poplar plantation study found that increased soil moisture, due to large rain events, increased overall stand transpiration (Chen et al. 2014). The 
negative effects on transpiration rates of the water-only treatment in 2013 may have been influenced by a reduction in sample size from instrument failure, a wounding effect from leaving sensors in trees for an extended period of time, or overall higher soil water in 2013 (Figure 1b) which may have lowered the overall difference in transpiration between the water-only treatment and control in 2013. Soil moisture availability appeared to not limit transpiration at any time during 2013, which may have resulted in no apparent change in transpiration levels between the control and water addition treatments. Additionally, an overabundance of precipitation in 2013 could have caused a saturation effect in the soil in the water-only treatment, causing a reduction in transpiration due to possible effects of anaerobic conditions on root and mycorrhizae function (Copolovici and Niinemets 2010). Overall, transpiration declines due to heating were likely primarily the result of soil moisture losses due to warming-induced evaporation under water-limited conditions, but could also be due in part to direct effects of warming on root physiology during months when water was not limiting.

\subsubsection{Interannual fluctuation of transpiration}

Our third hypothesis that there would be a greater effect from heat-only treatment on transpiration during drier years was supported. A trend for greater growing season precipitation and an increase in soil moisture content in years 2 and 3 (Figures $1 \mathrm{~b}$ and $3 \mathrm{~b}$ ) coincided with increases over time in sugar maple transpiration 
rates at both tree and stand scales (Figure 6). This moisture deficit was likely the result of precipitation not compensating for evaporative demand of the site in July and August, especially in 2011 (Burton et al. 2008). Another sugar maple study found a reduction in stomatal conductance when seedlings were exposed to a drought treatment (Tschaplinski et al. 1995). Overall, sugar maple transpiration patterns followed that of the rates of soil moisture during the growing season, especially in the heating-only treatment.

\subsubsection{Effects of environmental variables on transpiration}

Our final hypothesis was partially supported in that there was a linear relationship between daily stand transpiration $\left(E_{c}\right)$ rates and soil moisture (Table 1 and Figure 6b). However, our results suggested that transpiration was more responsive to $\mathrm{PPFD}_{\text {int }}$ than to any other variable measured (Table 2). Similarly, another sugar maple study found PAR and VPD to have the greatest influences on transpiration rates (Tang et al. 2006). A Swedish study found that Scots pine transpiration rates increased faster with increasing light than rates of Norway spruce, while both species' transpiration rates were only reduced by soil moisture when water levels fell below $80 \%$ field capacity (Lagergren and Lindroth 2002). A German study found that during periods of drought, sycamore maple reduced sap flux density by up to $37 \%$ compared to that occurring during periods of high soil moisture levels (Holscher et al. 2005), and Betsch et al. (2011) found up to an $80 \%$ reduction in 
transpiration in European beech during periods of drought (Betsch et al. 2011). Further, another study found PAR and VPD to be the strongest drivers of transpiration, while soil moisture was influential during periods of increasing VPD (Bovard et al. 2005). Fairly high soil moisture levels for this sugar maple ecotype during much of the growing season, even under heating, may have been responsible for the greater influence of $\mathrm{PPFD}_{\text {int }}$ than soil moisture. Light appears to be the limiting factor for transpiration (and likely carbon gain) more so than soil moisture or canopy VPD in this northern Great Lakes site where the growing seasons are short and relatively moist.

\subsubsection{Sources of error}

Various sources of error may have influenced the results of this study, including error associated with Granier's parameters (Steppe 2010) and not accounting for nocturnal transpiration (Oishi 2008) . Additional sources of uncertainty could be the results of scaling from sap flux density to the tree using DBH-sapwood allometry $\left(\mathrm{r}^{2}=0.84\right)$ and scaling to the stand-level using forest basal area measurements. Instrument failure alone caused up to $9 \%$ of sensors collecting raw voltage data to be erroneous. Sensors were often left in a sample tree for more than one growing season, which potentially led to underestimation of sap flux due to water column relocation, wounding response, and/or outward sapwood growth away from sensors (Lu et al. 2004, Moore et al. 2010). Despite these potential sources of error, the differences in transpiration rates across treatments were nonetheless 
relevant because they are relative to one another. In addition, stand-level fluxes are likely conservative because most of these artifacts of sap flux methodology tended to result in underestimations of transpiration rates (Steppe et al., 2010).

\subsection{Conclusions}

Overall, this study showed a significant reduction in sugar maple transpiration in response to experimental soil heating. When exposed to a combination heat+water treatment, there was no significant reduction in stand level transpiration in year 1 of the experiment, which likely indicated that the negative effect in the heating-only treatment was due primarily to soil water deficits and not soil temperature. Climate change is expected to increase mean annual temperature and frequency of drought in the Midwestern USA, especially in the southern region (Kunkel 2013). Canopy microclimate was not altered by our treatments, while under natural climate change both soil and canopy temperatures would be altered. Thus, our study results may be somewhat conservative in comparison to what may happen under real-world climate change scenarios (Figure 2 and 3). Our study has indicated that a reduction in potential transpiration due to drier soil could occur. This might contribute to factors responsible for dieback within sugar maple stands in the coming years, which could have negative impacts on stand ecology, stand structure, and productivity, and hence create a need for alternate management practices (Saxe et al. 2001). Alterations in canopy microclimate, namely VPD and $\mathrm{PPFD}_{\text {int }}$, could also negatively effect 
transpiration in sugar maple in the future. $\mathrm{PPFD}_{\text {int }}$ had a stronger effect on transpiration than soil moisture, overall, independent of treatment effects. Also, soil moisture had a greater impact on transpiration rates than canopy VPD. A decrease in transpiration rates due to insufficient soil moisture could cause a northern shift in the range of suitable habitat for sugar maple or potentially limit or alter the number of suitable sites within the species current range (Goldblum and Rigg 2005). Overall, in the future the warming-induced drought effects could exacerbate sugar maple sensitivity to climate change and potentially decrease sugar maple productivity and health on drier sites within its current range. Further research is needed to investigate effects of canopy warming on transpiration rates in various sugar maple ecotypes throughout its range. 


\subsection{Tables and Figures}

Table 2.1. Summary of ANCOVA results for test of environmental variable, treatment (Tmt), and variable $\mathrm{x}$ treatment effects on stand sap flow $\left(\mathrm{E}_{\mathrm{c}}, \mathrm{mm}_{\mathrm{day}}{ }^{-1}\right)$. Degrees of freedom (df), mean square, F-ration, and level of significant are list for main interaction and error terms. ${ }^{*} p<0.05, * * p<0.01, * * * p<0.001, \mathrm{NS}=$ nonsignificant.

\begin{tabular}{llll}
\hline Source & \multicolumn{3}{c}{$\mathrm{E}_{\mathrm{c}}\left(\mathrm{mm} \mathrm{day}^{-1}\right)$} \\
\cline { 2 - 4 } & $\mathrm{df}$ & Mean square & F-ratio \\
\hline PPFD & 1 & 1634.4 & $2843.1^{* * *}$ \\
Tmt & 3 & 87.0 & $151.3^{* * *}$ \\
PPFD x Tmt & 3 & 2.6 & $4.5^{* *}$ \\
Error & 1244 & 0.6 & $296.9^{* * *}$ \\
\hline Soil Moist & 1 & 492.9 & $14.4^{* * *}$ \\
Tmt & 3 & 23.9 & $3.8^{* *}$ \\
Soil moist x Tmt & 3 & 6.3 & \\
Error & 1756 & 1.7 & $582.8^{* * *}$ \\
& & & $67.1^{* * *}$ \\
VPD & 1 & 778.0 & $2.2 \mathrm{NS}$ \\
Tmt & 3 & 89.5 & \\
VPD x Tmt & 3 & 2.9 & $134.4^{* * *}$ \\
Error & 1496 & 1.3 & $125.7^{* * *}$ \\
& & & $9.2^{* * *}$ \\
Soil Temp & 1 & 197.5 & \\
Tmt & 3 & 184.8 & \\
Stemp x Tmt & 3 & 13.5 & \\
Error & 1720 & 1.5 &
\end{tabular}


Table 2.2. Partial $\mathrm{R}^{2}$ analysis for relationships between stand transpiration $\left(\mathrm{E}_{\mathrm{c}}, \mathrm{mm}\right.$ day $^{-1}$ ) and daily VPD, soil moisture, and PPFD. Intercepts, slopes coefficients, and $\mathrm{R}^{2}$ values are displayed for the linear regressions. $* p<0.05, * * p<0.01, * * * p<0.001, \mathrm{NS}=$ non-significant.

\begin{tabular}{|c|c|c|c|c|c|}
\hline & $\begin{array}{l}\text { Daytime } \\
\text { VPD only } \\
(\mathrm{kPa})\end{array}$ & $\begin{array}{l}\text { Daily soil } \\
\text { moisture } \\
\text { only }\left(\mathrm{cm}^{3}\right. \\
\left.\mathrm{cm}^{-3}\right)\end{array}$ & $\begin{array}{l}\text { Total } \\
\text { daytime } \\
\text { PPFD only } \\
\left(\mathrm{mol} \mathrm{m}^{-}\right. \\
\left.{ }^{2} \text { day }^{-1}\right) \\
\end{array}$ & $\begin{array}{l}\text { Daily soil } \\
\text { temperature } \\
\text { only }\left({ }^{\circ} \mathrm{C}\right)\end{array}$ & Full model \\
\hline$\beta_{0}$ & $3.0 * * *$ & $2.5 * * *$ & $1.2 * * *$ & $1.39 * * *$ & $-1.07 * * *$ \\
\hline$\beta_{1}$ & $1.8 * * *$ & $6.9 * * *$ & $0.046 * * *$ & $0.16^{* * *}$ & $\begin{array}{l}0.09 \text { (vpd) } \\
6.78 \text { (smoist)*** } \\
0.04(\text { ppfd }) * * * \\
0.08(\text { stemp) } * * *\end{array}$ \\
\hline $\mathrm{R}^{2}$ & 0.33 & 0.11 & 0.76 & 0.21 & 0.86 \\
\hline $\begin{array}{l}\text { Partial } \mathrm{R}^{2} \\
\text { for adding }\end{array}$ & 0.0005 & 0.08 & 0.26 & 0.03 & - \\
\hline
\end{tabular}


Table 2.3. Analysis for relationships between stand transpiration $\left(E_{c}, m^{\prime}\right.$ day $\left.^{-1}\right)$ and daily VPD, soil moisture, and PPFD within each treatment. Intercepts, slopes coefficients, and $\mathrm{R}^{2}$ values are displayed for the linear regressions. ${ }^{*} p<0.05$, $* * p<0.01, * * * p<0.001, \mathrm{NS}=$ non-significant.

\begin{tabular}{|c|c|c|c|}
\hline \multirow[t]{2}{*}{ Source } & \multicolumn{3}{|c|}{$\mathrm{E}_{\mathrm{c}}\left(\mathrm{mm}\right.$ day $\left.^{-1}\right)$} \\
\hline & $\beta_{0}$ & $\beta_{1}$ & $\mathrm{R}^{2}$ \\
\hline PPFD $_{\text {int }}-$ Control & $1.29 * * *$ & $0.05 * * *$ & 0.62 \\
\hline $\mathrm{PPFD}_{\text {int }}-$ Heat & $0.79 * * *$ & $0.04 * * *$ & 0.68 \\
\hline $\mathrm{PPFD}_{\text {int }}-$ Water & $1.54 * * *$ & $0.05 * * *$ & 0.75 \\
\hline $\mathrm{PPFD}_{\text {int }}-\mathrm{H}+\mathrm{W}$ & $1.12 * * *$ & $0.05 * * *$ & 0.74 \\
\hline SMoist - Control & $2.24 * * *$ & $8.39 * * *$ & 0.16 \\
\hline SMoist - Heat & $1.99 * * *$ & $7.65 * * *$ & 0.12 \\
\hline SMoist - Water & $3.49 * * *$ & $3.79 * *$ & 0.02 \\
\hline SMoist - H + W & $2.48 * * *$ & $7.51 * * *$ & 0.13 \\
\hline VPD - Control & $3.20 * * *$ & $1.70 * * *$ & 0.24 \\
\hline VPD - Heat & $2.54 * * *$ & $1.53 * * *$ & 0.26 \\
\hline VPD - Water & $3.40 * * *$ & $2.04 * * *$ & 0.34 \\
\hline VPD $-\mathrm{H}+\mathrm{W}$ & $3.06 * * *$ & $1.84 * * *$ & 0.31 \\
\hline STemp - Control & $1.88 * * *$ & $0.28 * * *$ & 0.15 \\
\hline STemp - Heat & $1.49 * * *$ & $0.10 * * *$ & 0.12 \\
\hline STemp - Water & $1.15 * * *$ & $0.22 * * *$ & 0.28 \\
\hline STemp - H + W & $1.53 * * *$ & $0.14 * * *$ & 0.15 \\
\hline
\end{tabular}



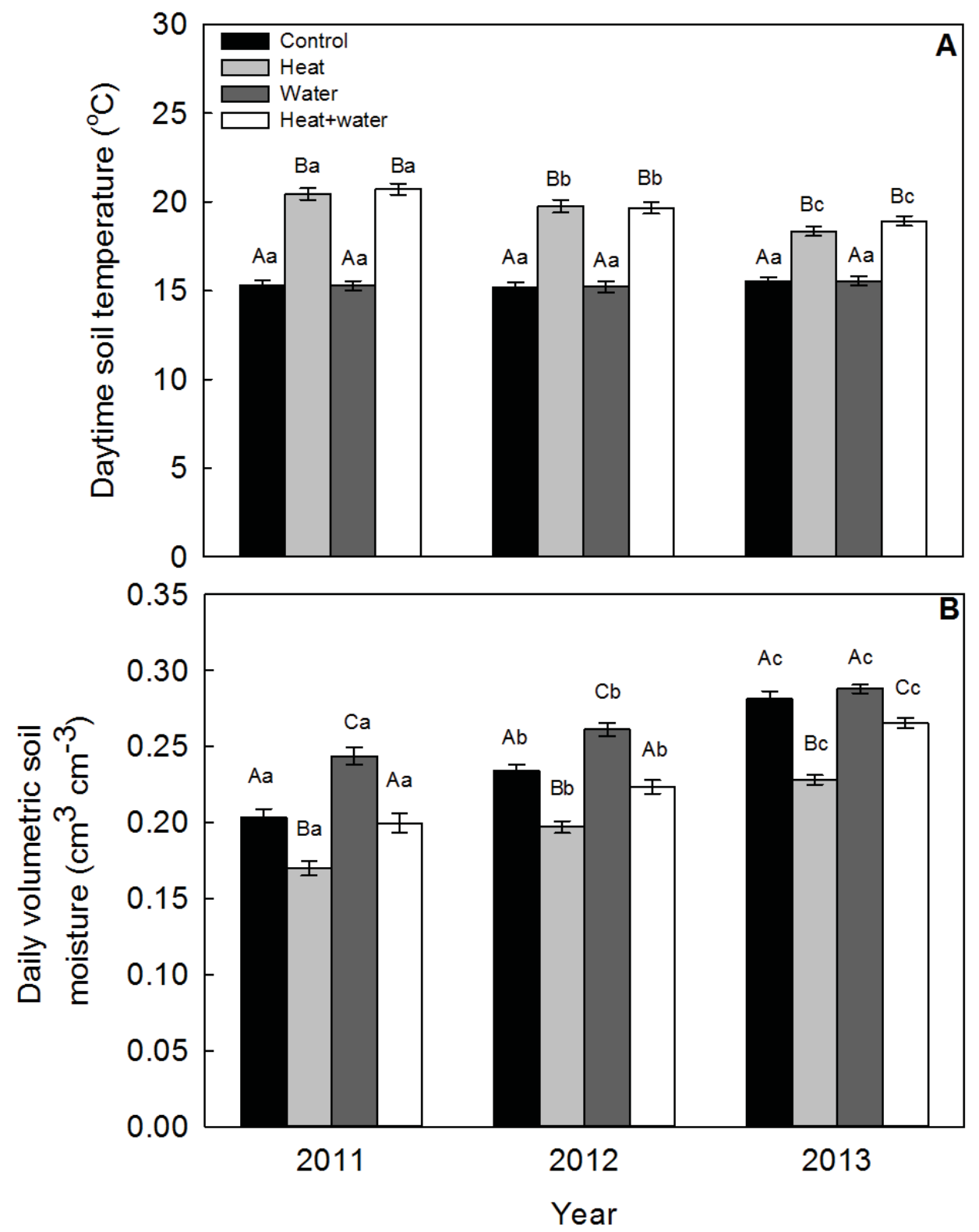

Figure 2.1. a) Mean daily daytime soil temperature and b) volumetric soil moisture during the period May to October 2011-2013. Capital letters indicate treatment effects within single years; lower case letters indicate significant differences within treatments, between years (Tukey HSD posthoc). 


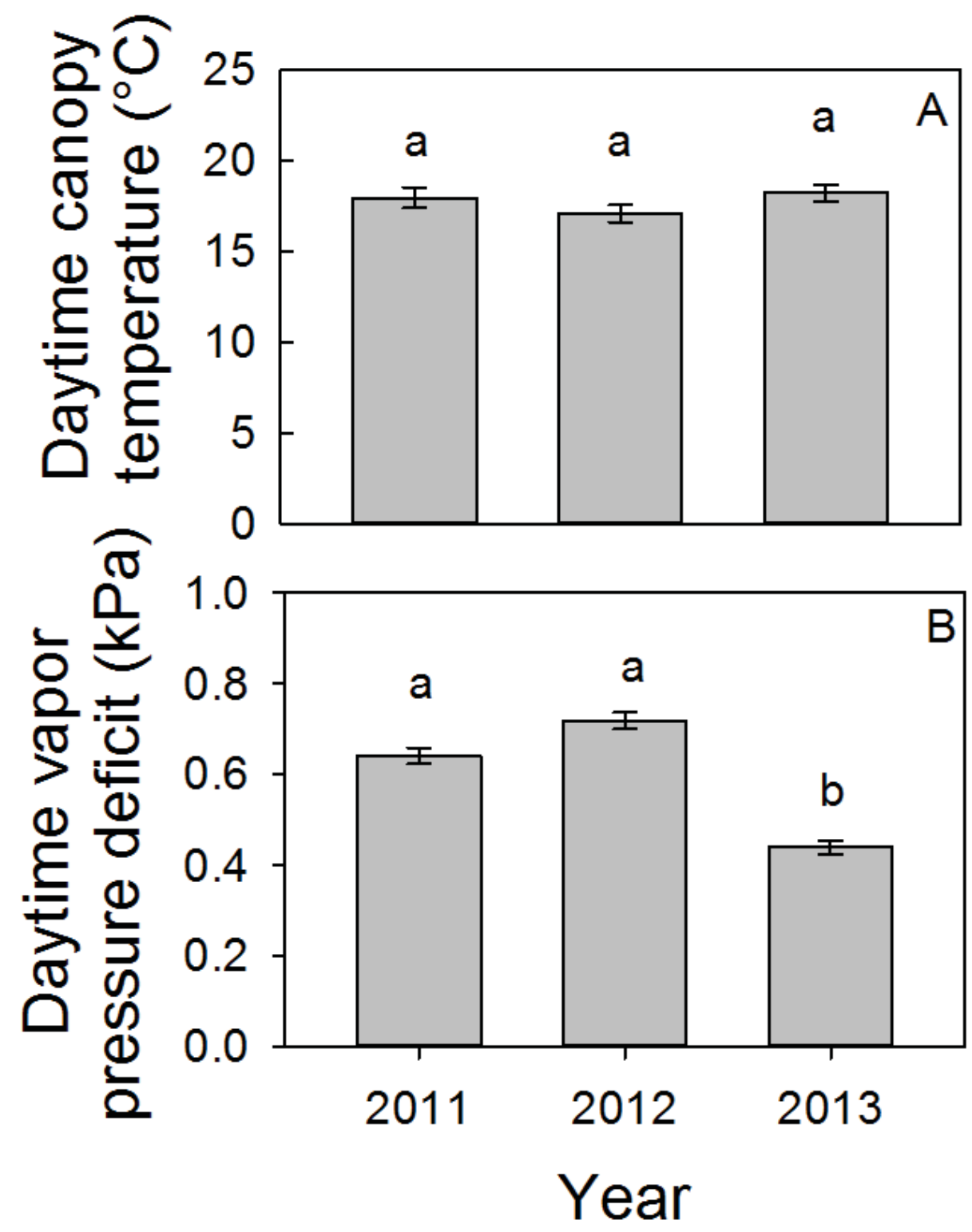

Figure 2.2. a) Daytime canopy temperature and b) daytime mean VPD at Ford forest during the period May to October 2011-2013. Lower case letters indicate significant difference between years. 


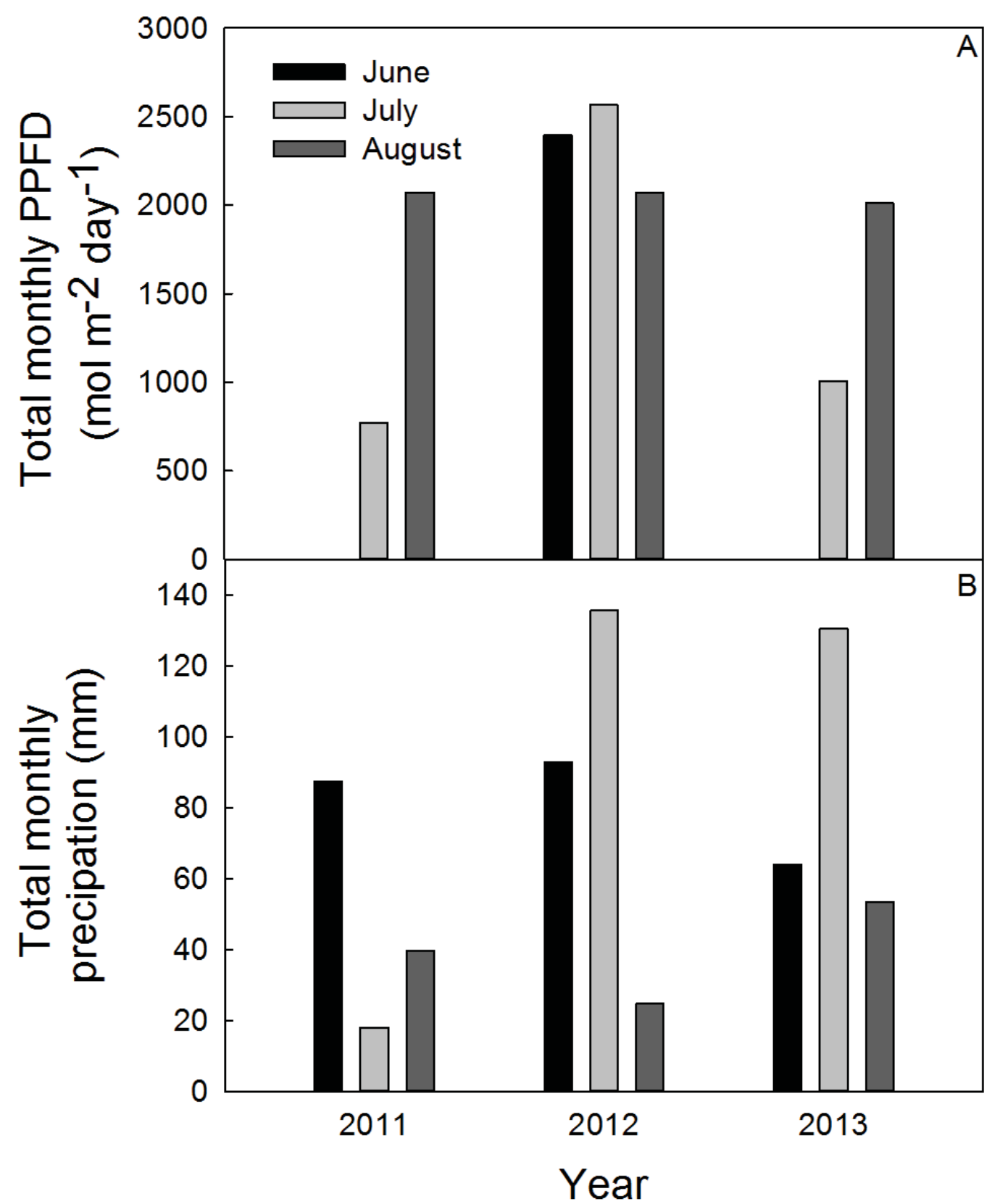

Figure 2.3. a) Monthly sum of daily mean daytime integrated photosynthetic photon flux density and b) monthly total precipitation at Ford Forest during the period May to October 2011-2013. 


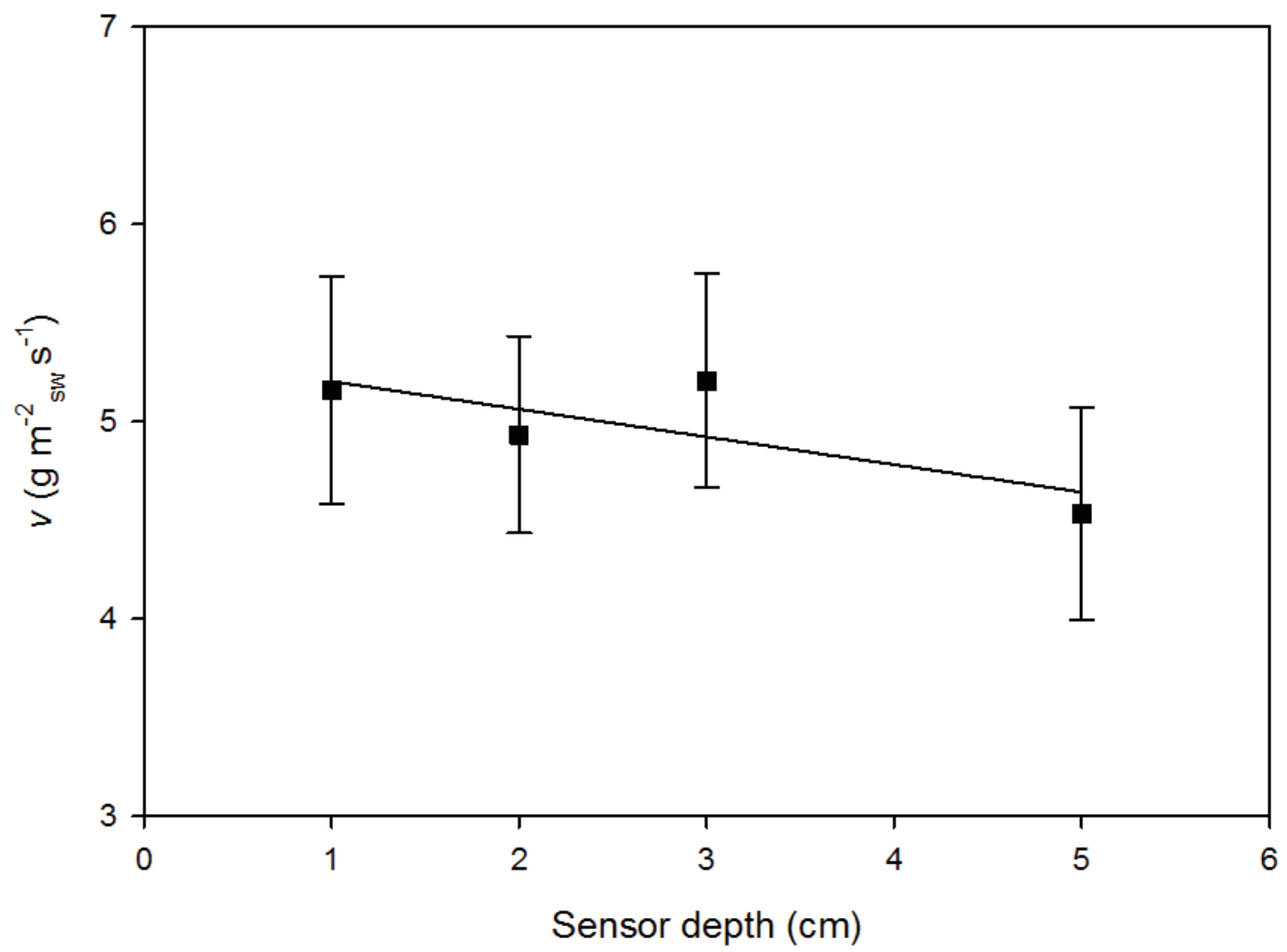

Figure 2.4. Mean sap flux density $(v)$ by sapwood depth. Error bars are one standard error of the mean $\left(P=0.001, \mathrm{r}^{2}=.61 ; \mathrm{y}=-0.1405 \mathrm{x}+5.3434\right)$. 


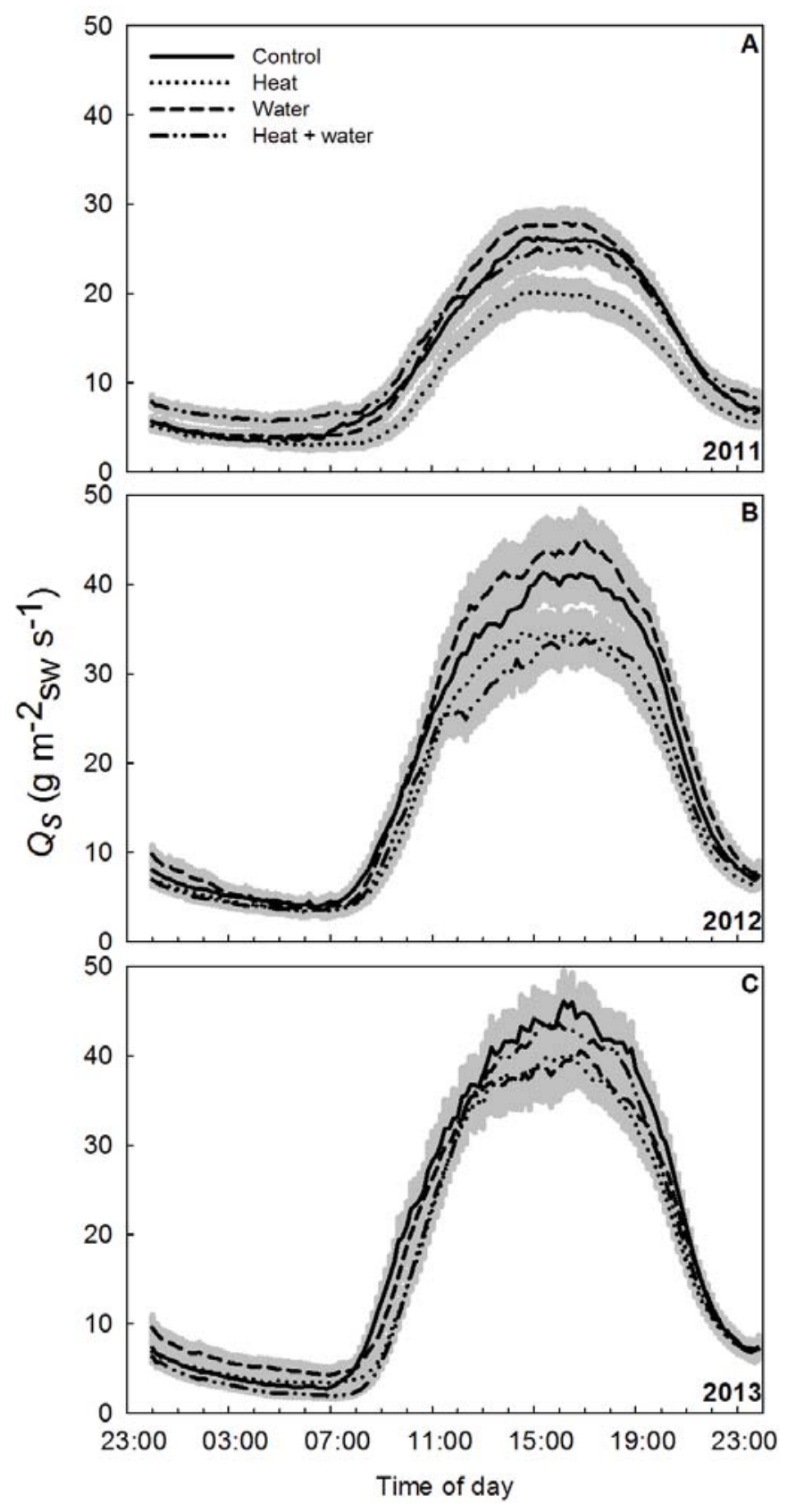

Figure 2.5. Mean diurnal tree level sap flux per unit sapwood area $\left(Q_{s}\right)$ for the four treatments for the 2011-2013 growing seasons (May-October). Grey shading indicates one standard error of the mean. 


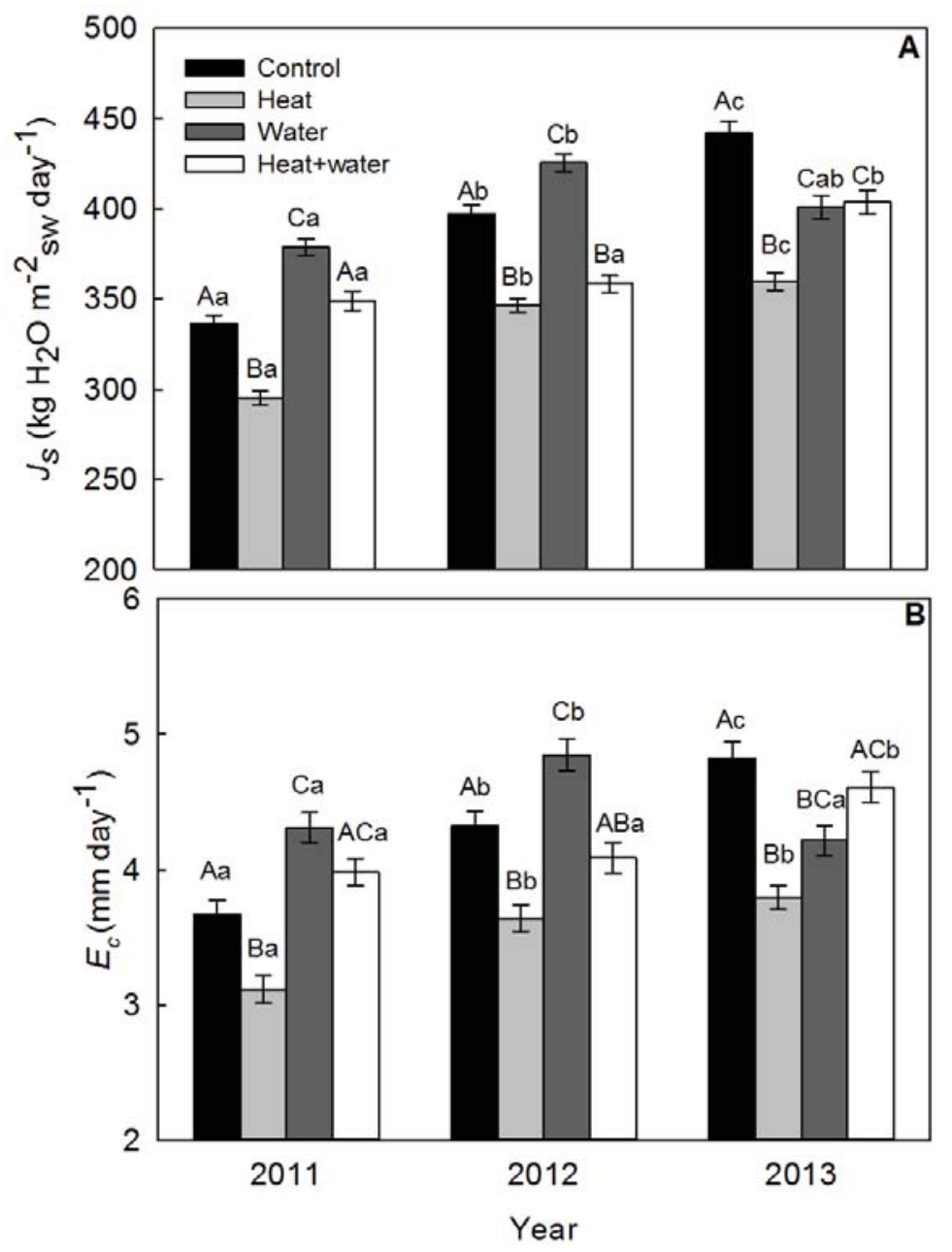

Figure 2.6. a) Mean daily sap flux per unit sapwood area $\left(J_{S}\right)$ and b) plot level transpiration $\left(E_{c}\right)$ for the four treatments for the 2011-2013 growing seasons (MayOctober). Error bars are one standard error of the mean for two plots per treatment. Stand level transpiration was effected by soil heating $(P=0.004)$ and water addition $(P=0.032)$, but not the treatment interaction $(P=0.356)$. Capital letters indicate Tukey HSD posthoc within single years; lower case letters indicate significant difference within single treatments between years. 

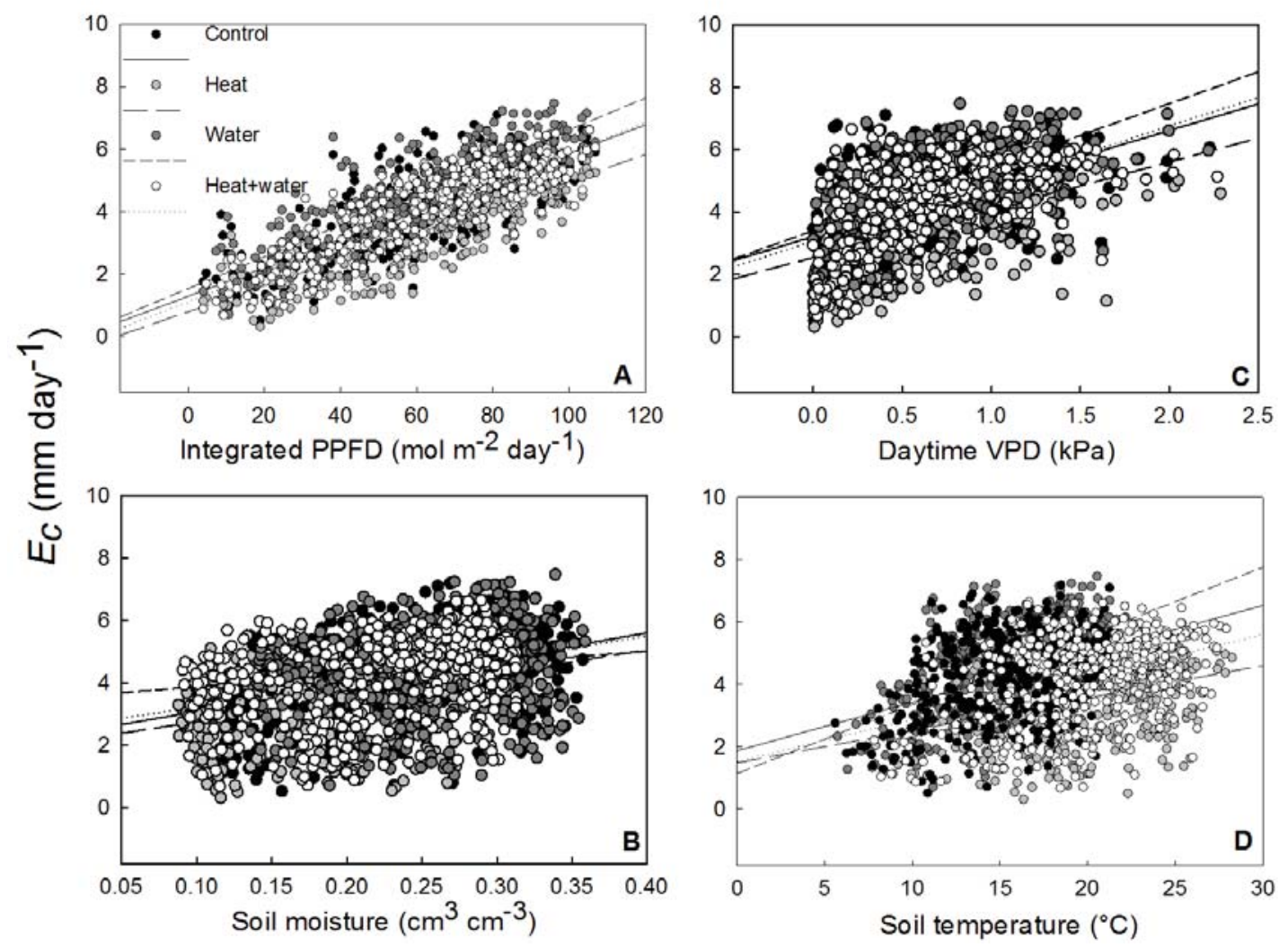

Figure 2.7. Relationships by treatment between daily stand level transpiration $\left(E_{c}\right)$ and a) daily integrated daylight, b) volumetric soil moisture, c) daytime VPD, and d) soil temperature. 


\subsection{References}

Auclair, A. N. D., W. E. Heilman, and B. Brinkman. 2010. Predicting forest dieback in Maine, USA: a simple model based on soil frost and drought. Canadian Journal of Forest Research-Revue Canadienne De Recherche Forestiere 40:687-702.

Bal, T., A. Storer, M. Jurgensen, P. Doskey, and M. Amacher. 2015. Nutrient stress predisposes and contributes to sugar maple dieback across its northern range: a review. Forestry 88:64-83.

Betsch, P., D. Bonal, N. Breda, P. Montpied, M. Peiffer, A. Tuzet, and A. Granier. 2011. Drought effects on water relations in beech: The contribution of exchangeable water reservoirs. Agricultural and forest meteorology 151:531543.

Bovard, B. D., P. S. Curtis, C. S. Vogel, H. B. Su, and H. P. Schmid. 2005. Environmental controls on sap flow in a northern hardwood forest. Tree Physiology 25:31-38.

Burton, A. J., J. M. Melillo, and S. D. Frey. 2008. Adjustment of Forest Ecosystem Root Respiration as Temperature Warms. Journal of Integrative Plant Biology 50:1467-1483.

Campbell, G. S. and J. M. Norman. 1998. An Introduction to Environmental Biophysics. 2nd edition. Springer, New York, NY. 
Chen, L., Z. Zhang, T. Zha, K. Mo, and Y. Zhang. 2014. Soil water affects transpiration response to rainfall and vapor pressure deficit in poplar plantation. New forests 45:235-250.

Copolovici, L. and U. Niinemets. 2010. Flooding induced emissions of volatile signalling compounds in three tree species with differing waterlogging tolerance. Plant, cell and environment 33:1582-1594.

Dermody, O., J. Weltzin, E. Engel, P. Allen, and R. Norby. 2007. How do elevated [CO2], warming, and reduced precipitation interact to affect soil moisture and LAI in an old field ecosystem? Plant and soil 301:255-266.

Ellsworth, D. S. and P. B. Reich. 1992. Water relations and gas exchange of Acer saccharum seedlings in contrasting natural light and water regimes. Tree Physiology 10:1-20.

Ewers, B. E., D. S. Mackay, J. Tang, P. V. Bolstad, and S. Samanta. 2008. Intercomparison of sugar maple (Acer saccharum Marsh.) stand transpiration responses to environmental conditions from the Western Great Lakes Region of the United States. Agricultural and forest meteorology 148:231-246.

Farrell, M. and R. Stedman. 2013. Landowner Attitudes Toward Maple Syrup Production in the Northern Forest: A Survey of Forest Owners with >= 100 Acres in Maine, New Hampshire, New York, and Vermont. Northern journal of applied forestry 30:184-187.

Filewod, B. and S. Thomas. 2014. Impacts of a spring heat wave on canopy processes in a northern hardwood forest. Global change biology 20:360-371. 
Frey, B. R., V. J. Lieffers, E. H. Hogg, and S. M. Landhausser. 2004. Predicting landscape patterns of aspen dieback: mechanisms and knowledge gaps. Canadian Journal of Forest Research-Revue Canadienne De Recherche Forestiere 34:1379-1390.

Gao, Q., P. Zhao, X. Zeng, X. Cai, and W. Shen. 2002. A model of stomatal conductance to quantify the relationship between leaf transpiration, microclimate and soil water stress. Plant, cell and environment 25:1373-1381.

Gebauer, T., V. Horna, and C. Leuschner. 2008. Variability in radial sap flux density patterns and sapwood area among seven co-occurring temperate broad-leaved tree species. Tree Physiology 28:1821-1830.

Godman, R. M., H. W. Yawney, and C. H. Tubbs. 1990. Sugar Maple (Acer saccharum Marsh.). . Handbook 654, U.S. Dept. Agric., For. Service, Washington D.C. .

Goldblum, D. and L. S. Rigg. 2005. Tree growth response to climate change at the deciduous-boreal forest ecotone, Ontario, Canada. Canadian Journal of Forest Research-Revue Canadienne De Recherche Forestiere 35:2709-2718.

Granier, A. 1985. A new method of sap flow measurement in tree stems. Annales des sciences forestières 42:193-200.

Granier, A. 1987. Evaluation of transpiration in a douglas-fir stand by means of sap flow measurements. Tree Physiology 3:309-319.

Gunderson, C. A., R. J. Norby, and S. D. Wullschleger. 2000. Acclimation of photosynthesis and respiration to simulated climatic warming in northern and 
southern populations of Acer saccharum: laboratory and field evidence. Tree Physiology 20:87-96.

Hinckley, T. M., P. M. Dougherty, J. P. Lassoie, J. E. Roberts, and R. O. Teskey. 1979. A severe drought: Impact on tree growth, phenology, net photosynthetic rate and water relations. Am. Midl. Nat 102:307-316.

Holscher, D., O. Koch, S. Korn, and C. Leuschner. 2005. Sap flux of five cooccurring tree species in a temperate broad-leaved forest during seasonal soil drought. Trees-Structure and Function 19:628-637.

Horsley, S. B., R. P. Long, S. W. Bailey, R. A. Hallett, and P. M. Wargo. 2002. Health of eastern North American sugar maple forests and factors affecting decline. Northern journal of applied forestry 19:34-44.

Houston, D. R. 1998. History of Sugar Maple Decline.in Sugar Maple Ecology and Health: Proceedings of an International Symposium - GTR-NE-2661. USDA Northeastern Research Station, Warren, Pennsylvania.

James, S. A., M. J. Clearwater, F. C. Meinzer, and G. Goldstein. 2002. Heat dissipation sensors of variable length for the measurement of sap flow in trees with deep sapwood. Tree Physiology 22:277-283.

Jarvi, M. P. and A. J. Burton. 2013. Acclimation and soil moisture constrain sugar maple root respiration in experimentally warmed soil. Tree Physiology 33:949-959. 
Kagawa, A., L. Sack, K. e. Duarte, and S. James. 2009. Hawaiian native forest conserves water relative to timber plantation: Species and stand traits influence water use. Ecological Applications 19:1429-1443.

Kratz, C. J. 2013. Impacts of Climate Change on Soil Microorganisms in Northern Hardwood Forests. School of Forest Resources and Environmental Science, Michigan Technological University, Houghton, MI.

Kunkel, K. E., L.E. Stevens, S.E. Stevens, L. Sun, E. Janssen, D. Wuebbles, S.D. Hilberg, M.S. Timlin, L. Stoecker, N.E. Westcott, and J.G. Dobson. 2013. Part 3. Climate of the Midwest U.S. Page 96 NOAA Technical Report NESDIS $142-3$.

Kuster, T., M. Arend, M. Guenthardt Goerg, and R. Schulin. 2013. Root growth of different oak provenances in two soils under drought stress and air warming conditions. Plant and soil 369:61-71.

Lagergren, F. and A. Lindroth. 2002. Transpiration response to soil moisture in pine and spruce trees in Sweden. Agricultural and forest meteorology 112:67-85.

Lu, P., L. Urban, and P. Zhao. 2004. Granier's thermal dissipation probe (TDP) method for measuring sap flow in trees: Theory and practice. Acta Botanica Sinica 46:631-646.

McDowell, N. 2011. Mechanisms linking drought, hydraulics, carbon metabolism, and vegetation mortality. Plant physiology 155:1051-1059.

Melillo, J., S. Butler, J. Johnson, J. Mohan, P. Steudler, H. Lux, E. Burrows, F. Bowles, R. Smith, L. Scott, C. Vario, T. Hill, A. Burton, Y.-M. Zhou, and J. 
Tang. 2011. Soil warming, carbon-nitrogen interactions, and forest carbon budgets. Proceedings of the National Academy of Sciences of the United States of America 108:9508-9512.

Millers, I., D. D. Shriner, and D. Rizzo. 1989. History of Hardwood Decline in the Eastern United States- NE-126. USDA Northeastern Experiment Station.

Moore, G., B. Bond, J. Jones, and F. Meinzer. 2010. Thermal-dissipation sap flow sensors may not yield consistent sap-flux estimates over multiple years. Trees 24:165-174.

Ni, B. R. and S. G. Pallardy. 1991. Response of gas-exchnage to water-stress in seedlings of woody angiosperms. Tree Physiology 8:1-9.

Norby, R. J. and Y. Q. Luo. 2004. Evaluating ecosystem responses to rising atmospheric $\mathrm{CO}(2)$ and global warming in a multi-factor world. New Phytologist 162:281-293.

Oishi, A. C. 2008. Estimating components of forest evapotranspiration: A footprint approach for scaling sap flux measurements. Agricultural and forest meteorology 148:1719-1732.

Poyatos, R., P. Llorens, and F. Gallart. 2005. Transpiration of montane Pinus sylvestris L. and Quercus pubescens Willd. forest stands measured with sap flow sensors in NE Spain. Hydrology and earth system sciences 9:493-505.

Prasad, A. M., L. R. Iverson, S. Matthews, and M. Peters. 2014. A Climate Change Atlas for 134 Forest Tree Species of the Eastern United States [database]. 
http://www.nrs.fs.fed.us/atlas/tree, Northern Research Station, USDA Forest Service. Delaware, Ohio.

Rustad, L. 2008. The response of terrestrial ecosystems to global climate change: towards an integrated approach. Science of the total environment 404:222235.

Rustad, L. E., J. L. Campbell, G. M. Marion, R. J. Norby, and M. J. Mitchell. 2001. A meta-analysis of the response of soil respiration, net nitrogen mineralization, and aboveground plant growth to experimental ecosystem warming. Oecologia 126:543-562.

Saxe, H., M. G. R. Cannell, B. Johnsen, M. G. Ryan, and G. Vourlitis. 2001. Tree and forest functioning in response to global warming. New Phytologist 149:369399.

Schmidt, W. P., F. Richter, M. Herbst, B. Schuldt, and N. Lamersdorf. 2014. Transpiration and water use strategies of a young and a full-grown short rotation coppice differing in canopy cover and leaf area. Agricultural and forest meteorology 195:165-178.

Steppe, K. 2010. A comparison of sap flux density using thermal dissipation, heat pulse velocity and heat field deformation methods. Agricultural and forest meteorology 150:1046-1056.

Tang, J., P. Bolstad, B. Ewers, A. Desai, and K. Davis. 2006. Sap flux-upscaled canopy transpiration, stomatal conductance, and water use efficiency in an old 
growth forest in the Great Lakes region of the United States. Journal of geophysical research 111.

Tschaplinski, T. J., D. B. Stewart, P. J. Hanson, and R. J. Norby. 1995. Interactions between drought and elavated $\mathrm{CO} 2$ on growth and gas-excahnge of seedlings of 3 deciduous tree species. New Phytologist 129:63-71.

USDA, N. A. S. S. 2014. Maple Syrup Production. Northeastern Regional Field Office, Harrisburg, PA.

van Herk, I. G., S. T. Gower, D. R. Bronson, and M. S. Tanner. 2011. Effects of climate warming on canopy water dynamics of a boreal black spruce plantation. Canadian Journal of Forest Research-Revue Canadienne De Recherche Forestiere 41:217-227.

Whitney, G. G. and M. M. Upmeyer. 2004. Sweet trees, sour circumstances: the long search for sustainability in the North American maple products industry. Forest ecology and management 200:313-333.

Wullschleger, S. D. and P. J. Hanson. 2006. Sensitivity of canopy transpiration to altered precipitation in an upland oak forest: evidence from a long-term field manipulation study. Global change biology 12:97-109.

Zhang, S. B., Z. K. Zhou, H. Hu, K. Xu, and N. Yan. 2005. Photosynthetic performances of Quercus pannosa vary with altitude in the Hengduan Mountains, southwest China. Forest ecology and management 212:291-301. 
Zhao, J. B., H. Hartmann, S. Trumbore, W. Ziegler, and Y. P. Zhang. 2013. High temperature causes negative whole-plant carbon balance under mild drought. New Phytologist 200:330-339.

Zhou, Y., J. Tang, J. Melillo, S. Butler, and J. Mohan. 2011. Root standing crop and chemistry after six years of soil warming in a temperate forest. Tree Physiology 31:707-717. 


\title{
3. The interspecific differences in water use and growth
}

\author{
between Populus tremuloides (trembling aspen) and Acer
}

rubrum (red maple) and their respective responses to short and long term climate variation ${ }^{2}$

\subsection{Abstract}

Annual temperature is expected to increase $3-5^{\circ} \mathrm{C}$ in the Upper Midwestern USA by 2100. Many tree species are expected to decline in this region and species may migrate north from southern ecosystems. For example, the suitable habitat for trembling aspen range (Populus tremuloides) is expected to move northward, whereas red maple (Acer rubrum) is not expected to be altered by climate change within its current range. The objective of our study was to investigate the interspecific differences in water use between trembling aspen and red maple in a mixed hardwood stand and the responses to short- term (daily) climate variation. We also investigated the interspecific differences in growth and water use efficiency (WUE) between trembling aspen and red maple to identify potential responses to long- term (interannual) climate variation as estimated using annual values of Palmer Drought Severity Index (PDSI). We measured sap flux of 10 individual red maple and 10 trembling aspen trees within a $6000 \mathrm{~m}^{2}$ area over three growing seasons. We expected that: 1) aspen would have higher rates of daily transpiration than maple during all

\footnotetext{
${ }^{2}$ This chapter is in preparation for submission to the peer-reviewed journal Tree Physiology.
} 
years of the study, 2) aspen would be less sensitive than maple to changes in soil moisture in regards to daily transpiration rates, and as a result 3) aspen would have higher rates of annual growth compared to maple. Additionally, we hypothesized that 4) aspen would have higher rates of annual WUE compared to maple, because it would be less susceptible to alterations in its environment. Our results showed trembling aspen had greater rates of transpiration in every year of study compared to red maple. Trembling aspen rates of transpiration were influenced by both soil moisture and solar radiation, while red maple transpiration was influenced primarily by VPD. Additionally, trembling aspen had higher rates of growth and WUE than red maple in our long term study. Low levels of soil moisture and PDSI both increased trembling aspen transpiration and growth. This could indicate that trembling aspen may not react as unfavorably to climate change as expected, in northern Minnesota. Alterations in aspen habitat in its southern range may force a northern shift in the species where suitable habitat exists.

\subsection{Introduction}

The Midwestern United States will be subjected to increased annual temperatures as a result of global climate change, according to recent studies. Average annual temperature are projected to rise $3.8-4.9^{\circ} \mathrm{C}$ in the Midwestern USA by the year 2065 (Pryor et al. 2014). Annual precipitation rates are expected to increase $10-20 \%$ in the Midwestern USA, with the largest increases occurring in the 
dormant winter and fall seasons (Kunkel 2013, Pryor et al. 2014). The percentage of annual precipitation occuring within the ten wettest days of the year, a measure of precipitation intensity, is also expected to increase (Kunkel 2013). As a result, droughts are also likely to become more frequent and intense for the Midwestern U.S. in the the coming decades (Knapp et al. 2008), even though there has been no change in drought duration in the Midwest in the last 100 years (Dai 2010). Forest composition will likely be altered as a result of such climate change in the coming century.

Many species are expected to decline in the northern Midwest as habitat becomes more suitable for drought tolerant species, such as Quercus and Pinus (Iverson et al. 2008). The trembling aspen range (Populus tremuloides) is expected to move northward under certain emission models, while red maple (Acer rubrum) range is not expected much to be altered with climate change (Prasad et al. 2014). High levels of stress can cause dieback, which is the death of branches within a crown from the terminal end toward the center of the crown, within a stand (USDA Forest Service 2004, Auclair et al. 2010). Trembling aspen dieback is increasing across the American Upper Midwest, yet the primary drivers of this phenomenon are poorly understood. Aspen dieback could occur for several reasons, including extreme weather events, such as late winter thaw or spring storms, which can weaken stands by damaging buds, roots, and crowns (Frey et al. 2004). As dieback increases in a stand, remaining trees are subjected to increased levels of solar radiation, wind, and evaporative stresses which increase the possibility of additional dieback (Frey et al., 
2004). As climate change may increase the variability in weather, understanding how meteorological events affect water use and productivity in aspen may aid in better understanding dieback dynamics (Christensen et al. 2007)

Species-specific shade tolerance may affect how different species use water within an ecosystem. Within aspen dominated forests, common in Northern Minnesota, trembling aspen does not occur as a subdominant species because of its extreme shade intolerance (Perala 1990). However, red maple is moderately tolerant of shade and is a common subdominant species (Walters and Yawney 1990). Red maple's shade tolerance and ability to respond with increased growth after release from shade makes it a later successional tree species in eastern North America (Palik and Pregitzer 1992). Shade tolerant species are able to photosynthesize in the shaded forest understory but tend to gain carbon at relatively lower rates (Poorter 2009).

A decrease of transpiration occurs when demand for carbon is low. Shade intolerant species, on the other hand, are able to gain carbon at higher rates in highlight conditions (Poorter 2009). However, shade tolerance has been found to be negatively correlated with drought tolerance (Niinemets and Valladares 2006). A study found that, when compared to 5 oak species (more shade intolerant), red maple leaves had substantially lower rates of photosynthesis and conductance (Barton and Gleeson 1996). The authors suggested that the difference was the result of the higher tolerance of dehydration and high temperature in oak leaves (Barton and Gleeson 1996). Even though aspen growth could still decline with declining soil moisture, 
this shade intolerant species could still maintain higher rates of carbon gain compared to shade tolerant species, like red maple (Hogg and Hurdle 1995). Extreme weather events could induce different responses for early successional and late successional tree species. Late successional plants tend to be more sensitive to a decrease in moisture levels than early successional plants (He et al. 2005). Since red maple is a late successional species it may be more sensitive to a decrease in moisture levels than the early successional trembling aspen. A dendrochronology study found that even though red maple saplings showed no radial growth decline during a period of drought, mature trees experienced growth reductions during a period of drought $(\mathrm{He}$ et al. 2005). Additionally, a study conducted in Ontario found that radial growth in trembling aspen was not affected by drought (Cooke and Roland 2007).

The ability to maintain radial growth during a drought may indicate the ability to maintain carbon gain through high water use efficiency (WUE), the ratio of photosynthesis to transpiration (Ponton et al. 2001). Plants can achieve high WUE through either high net photosynthesis, or low transpiration, or both due to partial regulation by stomatal conductance (Zhang et al. 1997). Under dry conditions, plants with a high WUE should have higher productivity or a greater ability to survive than plants with a low WUE (Zhang et al. 1997). A Chinese eddy covariance study found that interannual variation in Boral aspen WUE was controlled mostly by soil moisture levels (Tong 2014), while a Great lakes sap flux study found sugar maple WUE to be correlated with PAR and VPD (Tang et al. 2006). 
In north-central Minnesota, we investigated the interspecific differences in water use between trembling aspen (Populus tremuloides) and red maple (Acer rubrum) in a mixed hardwood stand, to find a response to short-term (minutes-days) climate variation. We also investigated the interspecific differences in growth and WUE between trembling aspen and red maple to identify a response to long- term (interannual) climate variation. We hypothesized that: 1) aspen will have higher rates of daily transpiration than maple during all years of the study, 2) aspen would be less sensitive than maple to changes in soil moisture in regards to daily transpiration rates, and as a result 3) aspen would have higher rates of annual growth compared to maple. Additionally, we predicted 4) aspen would have higher rates of annual WUE compared to maple, because it would be less susceptible to alterations in its environment. Overall, we hypothesize that aspen would be less sensitive to its environment, due to drought tolerance, allowing it to transpire and grow at a higher rate than maple, a later successional drought intolerant species.

\subsection{Materials and Methods}

\subsubsection{Study site and experimental design}

The trembling aspen/ red maple stand selected for the study was located outside of Grand Rapids, Minnesota, within the USDA Forest Service Marcell Experimental Forest (MEF) $\left(47^{\circ} 32^{\prime} \mathrm{N}, 93^{\circ} 28^{\prime} \mathrm{W}\right)$. The mean annual temperature at 
the MEF since 1961 was $3.4 \pm 13.0^{\circ} \mathrm{C}$ (Sebestyen et al. 2011). The monthly mean temperature was $18.9 \pm 3.3^{\circ} \mathrm{C}$ during July and $-15.1 \pm 8.2^{\circ} \mathrm{C}$ during January (Sebestyen et al. 2011). The mean annual precipitation was $78.0 \pm 11.0 \mathrm{~cm}$ (Sebestyen et al. 2011). More precipitation occurs during summer months than winter. The study site was a successional aspen-dominated mixed hardwood stand with trembling aspen (Populus tremuloides), bigtooth aspen ( $P$. grandidentata), balsam poplar $(P$. balsamifera), paper birch (Betula papyrifera), balsam fir (Abies balsamea), and red maple (Acer rubrum) dominating the canopy (Sebestyen et al. 2011). The soils at the study site were predominantly sandy loams consisting of Menahga sand (mixed frigid Typic Udipsamments) and Graycalm loamy sands (Isotic, frigid Lamellic Udipsamments: (Sebestyen et al. 2011)).

Sap flux was measured in 10 individual red maple (16-27 cm DBH) and 10 trembling aspen trees (30-45 cm diameter at breast height, DBH) within both plots, totaling 20 trees. All trees were in an area encompassing $6000 \mathrm{~m}^{2}$. Sap flux was measured between mid- May and mid-October, from 2011 through 2013. In September 2011, three cores were extracted, to test dendrochronology and water use efficiency, from each of three dominant trembling aspen and three dominant red maple trees (both >30 cm DBH), outside of sap flux study area. Daytime air temperature, soil temperature, VPD, PPFD, daily volumetric soil moisture, and seasonal precipitation were measured in a field near the study site. 


\subsubsection{Determination of sapwood depth}

Sample trees outside of study plots were used to determine sapwood depth. The sample trees were selected by using a random number between 0 and 50 to determine distance from the beginning of the $50 \mathrm{~m}$ transect to the nearest tree, repeated 20 times without resampling the same trees. To determine sapwood thickness trees were cored at breast height in April of 2011 using a stainless steel increment borer (18”, 5 mm, Haglof Company Group, Sweden). Cores were placed in a chilled light-proof container of tetrazolium (TTZ) vital stain for 48 hours (SigmaAldrich, St. Louis, MO). The TTZ stained the living cells of the sapwood pink, and dyed cores were measured for sapwood thickness to the nearest mm using a ruler and a 10X dissection microscope (SZ, Olympus Optical Co., Tokyo, Japan). Cores were shaved with a razor blade to make dyed cells clearly visible. The linear regression relationship between $\mathrm{DBH}$ and sapwood depth was then used to estimate sapwood depth of trees on study plots, based on their DBH.

\subsubsection{Sap flux}

Xylem sap flux was measured using variable-length heat dissipation sap flux sensors based on the design of Granier $(1985,1987)$ and modified by James et al. (2002). Sensors consisted of two probes, each with a $1 \mathrm{~cm}$ long aluminum tip containing a copper-constantan thermocouple junction. Each upper (downstream) probe was heated with a coil of nichrome wire, yielding a resistance of approximately $100 \mathrm{ohms}$ per sensor. Pairs of probes were installed $10 \mathrm{~cm}$ apart vertically, and at 
several depths per tree to account for radial variability in sap flux with sapwood depth (Gebauer et al. 2008). For trees 8-10 cm DBH, sensors were inserted into the sapwood at depths of 1,2 , and $3 \mathrm{~cm}$, and for trees $>10 \mathrm{~cm} \mathrm{DBH}$, sensors were inserted at 1, 3, and $5 \mathrm{~cm}$ depths. The three sap flux sensors per tree were vertically staggered near breast height, and at least $20 \mathrm{~cm}$ apart horizontally to prevent heating overlap. Reflective insulation (Reflectix, Inc., Markleville, IN) was wrapped around each instrumented tree to prevent an external thermal gradient (Lu et al. 2004). Deepcycle batteries (12 V, 105 AH; model M2 and M3 Diehard, Sears, Hoffman Estates, IL) supplied power through a voltage regulating station to heat the upper (heated) probes. Batteries were constantly charged by an alternating current source within site, and voltage was individually set for each sensor to yield an output of $0.15 \mathrm{~W}$ per heated probe. The temperature difference, determined from the voltage differential between the two thermocouple tips in the heated and unheated probes, was measured every minute, and the average was logged every 10 minutes with CR1000 dataloggers and 32 channel relay multiplexers (Campbell Scientific, Logan, UT). Sensors found to be faulty were replaced as needed.

Temperature differences between probes in each sensor were converted to sap flux densities $\left(v ; \mathrm{g} \mathrm{m}^{-2} \mathrm{~s}^{-1}\right)$ based on Granier's empirical calibration method (Granier 1987, Gebauer et al. 2008):

$$
v=119 \times\left(\frac{\Delta V_{m}-\Delta V}{\Delta V}\right)^{1.231}
$$


where $\Delta V$ is the difference in voltage between the two thermocouples for each 10 minute interval and $\Delta V_{\mathrm{m}}$ is the daily maximum difference in voltage, corresponding to minimum daily sap flux density. Sap flux was scaled up to whole tree sap flux $(Q$, $\mathrm{g} \operatorname{tre}^{-1} \mathrm{~s}^{-1}$ ) by summing sap flux densities across all annuli of sapwood for each tree:

$$
Q=\sum_{i=1}^{n} \pi\left(r_{i}^{2}-r_{i-1}^{2}\right) v_{i} .
$$

where $r_{i}$ was the exterior radius $(\mathrm{cm}), r_{i-1}$ was the interior radius $(\mathrm{cm})$, and $v_{i}$ was the sap flux density $\left(\mathrm{g} \mathrm{m}^{-2} \mathrm{~s}^{-1}\right)$ of the $i^{\text {th }}$ annuli (Kagawa et al. 2009). Sap flux per unit sapwood area for each tree $\left(Q_{s} ; \mathrm{g} \mathrm{m}_{\text {sw }}^{-2} \mathrm{~s}^{-1}\right)$ was determined by dividing whole tree sap flux $(Q)$ by the sapwood area of each tree. Daily sap flux per tree $\left(J ; \mathrm{kg} \mathrm{tree}^{-1}\right.$ day $^{-1}$ ) was calculated by summing the ten minute intervals of $Q$ for each 24 hour period. Daily sap flux per unit sapwood area $\left(J_{s} ; \mathrm{kg} \mathrm{m}^{-2}\right.$ sapwood day $\left.{ }^{-1}\right)$ for each tree was calculated by dividing whole tree rates $(J)$ by total sapwood area per tree. Finally, plot level transpiration $\left(E_{c}, \mathrm{~mm} \mathrm{day}^{-1}\right)$ was calculated using the following equation (Tang et al. 2006):

$$
E_{c}=J * \frac{A_{s}}{A_{g}}
$$

where $A_{s}$ was the total sapwood area $\left(\mathrm{m}^{2}\right)$ of the study plots, estimated from total basal area of the stand, and $\mathrm{A}_{\mathrm{G}}$ was the total area of the plots $\left(\mathrm{m}^{2}\right)$.

A linear regression equation between sap flux density and sapwood depth was used to gap-fill missing data due to sensor failure and to estimate sap flux rates of unmeasured sapwood annuli for all trees. In order to gap-fill missing daily data $\left(J_{s}\right)$, a 
multiple regression model was developed with $J_{s}$ as the dependent variable and daily values of soil temperature, volumetric soil moisture, canopy air temperature, canopy VPD, photosynthetically active photon flux density (PPFD), and ambient precipitation as the independent variables. A backward elimination model selection procedure was used to find the best fit model for prediction of $J_{s}$. Daily $J_{s}$ values were then calculated based on the best fit model and environmental conditions of the missing day.

\subsubsection{Dendrochronology}

A $5 \mathrm{~mm}$ stainless steel increment core borer at breast height $(1.5 \mathrm{~m})$ was used to extract wood cores for dendrochronology measurements. Two whole wood cores from each tree were air dried, mounted to wooden boards with glue and sanded. The third core was frozen for subsequent isotopic analysis. Ring-width series from two cores per tree were measured to the nearest $0.01 \mathrm{~mm}$ under a binocular microscope with a sliding stage micrometer (ACU-RITE, Schaumburg, IL.) The program COFECHA was used to identify missing, partial or false rings (Grission-Mayer 2001). COFECHA accomplishes cross-dating by calculating better correlation coefficients for different lags between distinct segments of each individual ring-width series and a dating master series (Rozas 2003). This was accomplished by matching patterns of wide and narrow rings between the three whole wood cores from the same tree (Rozas 2003). 
Once years were established using cross-dating, interannual rings formed between 1990 and 2010 were separated for stable carbon isotope analysis from the third whole wood core from each tree using a razor blade under a dissecting microscope (Eglin et al. 2008). Wood samples were pulverized with a ball mill and stable carbon isotope values were recorded using continuous flow isotope ratio mass spectrometry at the Forest Ecology Stable Isotope Laboratory at Michigan Technological University (ThermoFinnigan Delta Plus mass spectrometer, Waltham, MA). Values of $\delta^{13} \mathrm{C}$ were calculated using the standard delta notation:

$$
\delta^{13} \mathrm{C}=(\text { Rsample } / \text { Rstandard }-1) 1000 \quad \text { Eq. } 4
$$

where $R$ is the ratio of the heavy isotope $\left({ }^{13} \mathrm{C}\right)$ to the lighter isotope $\left({ }^{12} \mathrm{C}\right)$. The photosynthetic $\Delta{ }^{13} \mathrm{C}(0 / 00)$ discrimination is used to differentiate variation in ${ }^{13} \mathrm{C}$ source material (Farquhar 1989, Chen 2011):

$$
\Delta=\frac{\delta a-\delta p}{1+\delta p} X 1000
$$

Where $\delta \mathrm{a}$ is the $\mathrm{C}$ isotope ratio atmospheric $\mathrm{CO}_{2}$ and $\delta \mathrm{p}$ is plant carbon ratio.

\subsubsection{Environmental measurements}

A weather station was located in an open field $\sim 30 \mathrm{~m}$ from the study area. Daytime mean air temperature was averaged from half hourly data measured using a hygrothermograph with a $0.55^{\circ} \mathrm{C}$ resolution (Belfort model 594-1). Daily precipitation was measured using a precipitation gauge with a $0.025 \mathrm{~cm}$ resolution 
(Belfort Universal Recording Precipitation Gauge 2-1 with wind shield). Mean daily soil available water was averaged from half hourly data measured using a moisture gauge with a $0.025 \mathrm{~cm}$ resolution (Troxler Series 4300 Depth Moisture Gauge). The readings were taken at $0.3 \mathrm{~m}$ intervals to a maximum of $3 \mathrm{~m}$. Mean annual air temperature, mean annual and total precipitation have been measured at the Marcell Experimental Forest since 1960 (Verry and Elling 2011). Mean daytime VPD was calculated using the following equation (Campbell and Norman 1998):

$$
\mathrm{VPD}=(a \exp (b \mathrm{~T} / \mathrm{T}+c)) *(1-h r) \quad \text { Eq. } 6
$$

where the environmental constants are $a=0.611 \mathrm{kPa}, b=17.502$, and $c=240.97^{\circ} \mathrm{C}$, while $\mathrm{T}$ was temperature $\left({ }^{\circ} \mathrm{C}\right)$ and $h r=$ relative humidity $(\%)$. Integrated photosynthetically active photon flux density $\left(\mathrm{PPFD}_{\mathrm{int}} ; \mathrm{mol} \mathrm{m}^{-2} \mathrm{day}^{-1}\right)$ was measured at a 10 minute resolution starting in July 2011. PPFD ${ }_{\text {int }}$ was measured $2 \mathrm{~m}$ above the soil surface in a field approximately $30 \mathrm{~m}$ away from the plots, to ensure there was no shading due to buildings or trees (Hobo photosynthetic light (PAR) smart sensor with Micro station data logger, Onset Computer Corporation, Bourne, MA). The PAR sensor was mounted facing south to further ensure no shading was occurring.

\subsubsection{Data analysis}

Linear regressions were used to determine relationships between sapwood depth and DBH and between sap flux and sapwood depth for each species. Analysis of variance (ANOVA) was used to compare daily and interannual differences in 
growing season daytime air temperature, soil temperature, VPD, $\mathrm{PPFD}_{\text {int }}$, and daily volumetric soil water content. ANOVAs were used to compare interannual $\mathbf{J}_{\mathrm{s}}$ and $E_{c}$ between two species. Regressions were used to investigate the relationship between

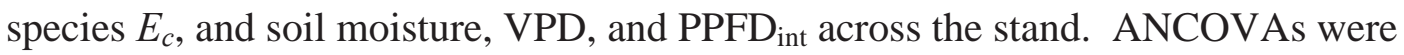
used to compare interannual growth or ${ }^{13} \mathrm{C}$ between species with growing season regional Palmer Drought Severity Index (PDSI) as a covariate. A partial regression analysis was also used to determine the importance of PPFD int $_{\text {, VPD, and soil }}$ moisture on mean daily $E_{c}$ by removing the variable from the model and comparing the partial model $\mathrm{R}^{2}$ to the full model $\mathrm{R}^{2}$ to determine the variable's relative contribution to explained variability. Data analyses were performed with the statistical package $R$ (R Core Team 2014).

\subsection{Results}

\subsection{Environmental variables}

Daytime air temperature increased with each subsequent year (Fig. 1a), and daytime soil temperature was higher in 2013 when compared to 2011 and 2012 (Fig. 1b). Neither daytime VPD nor PPFD ${ }_{\text {int }}$ were different across the years of study (Fig. 1c and e). Volumetric soil water content was greatest in 2011, while 2012 had the lowest soil moisture levels (Fig. 1d). Precipitation, as snow, prior to the 2013 growing season was the highest of the three years of study, while during the 2011 
growing season precipitation, as rain, was the highest of three years (Fig. 1f). All variables, except precipitation, were from the growing season only (May-Oct) during the study.

\subsubsection{Sap flux}

Both red maple and trembling aspen sapwood thickness linearly increased with DBH (red maple; $P=0.001, \mathrm{r}^{2}=.73$ and trembling aspen $P=0.001, \mathrm{r}^{2}=.85$ ):

Sapwood thickness $_{\mathrm{rm}}=0.1324 * \mathrm{DBH}+0.3912$

Sapwood thickness $_{\mathrm{ta}}=0.3061 * \mathrm{DBH}+0.363$

Eq. 8

These relationships were used to estimate total sapwood depth for probe placement and sapwood area measurements.

Mean instantaneous sap flux per unit sapwood area $\left(Q_{s}\right)$ was measured between species across all years of study. Trembling aspen had greater rates of $\mathrm{Q}_{\mathrm{s}}$ when compared to red maple in all years of study (Fig. 2). Both species had peak $\mathrm{Q}_{\mathrm{s}}$ around 16:00 hrs (Fig. 2). Red maple also had two peaks in 2012 and 2013, the smaller of which occurring around 11:00 hrs (Fig 2a). The greatest rate of $\mathrm{Q}_{\mathrm{s}}$ in red maple and trembling aspen occurred in 2012 and 2011, respectively (Fig 2).

Total daily sap flux per unit sapwood area $\left(\mathrm{J}_{\mathrm{S}}\right)$ was measured between species across all years of study. Red maple $\mathrm{J}_{\mathrm{s}}$ in 2012 was greater than 2011, while 2013 showed the lowest $\mathrm{J}_{\mathrm{s}}$ of study (Fig. 3a). Trembling aspen $\mathrm{J}_{\mathrm{s}} 2011$ was greater than 
rates from 2013, while 2012 was not different from the other years of study (Fig. 3a). Trembling aspen had a mean daily $\mathrm{J}_{\mathrm{s}}$ rate 99,82 , and $107 \%$ greater than red maple in 2011, 2012, and 2013, respectively (Fig. 3a). When scaled up to the plot-level ( $\left.\mathrm{E}_{\mathrm{c}}\right)$, there were similar patterns as $\mathbf{J}_{\mathrm{s}}$ for red maple and trembling aspen (Fig. 3b). Trembling aspen had a mean daily $\mathrm{E}_{\mathrm{c}}$ rate 83,67 , and $89 \%$ greater than red maple 2011, 2012, and 2013, respectively (Fig. 3b).

\subsubsection{Influence of environmental variables on daily sap flux}

Results from the regressions indicated that plot-level transpiration rates $\left(\mathrm{E}_{\mathrm{c}}\right)$ increased linearly with increasing VPD for red maple (Table 1 and Figure 4c). Yet, red maple $\mathrm{E}_{\mathrm{c}}$ was not affected by soil moisture or $\mathrm{PPFD}_{\text {int }}$ (Table 1 and Figure 4). Additionally, partial regression analysis showed that VPD had the greatest influence of the three environmental variables on red maple $\mathrm{E}_{\mathrm{c}}$, although the full model only explained $7 \%$ of the variability in $\mathrm{E}_{\mathrm{c}}$ (Table 1). For trembling aspen, all three environmental variables showed linear relationships with $\mathrm{E}_{\mathrm{c}}$, although $\mathrm{PPFD}_{\text {int }}$ explained the highest amount of variability, and soil moisture was more influential than VPD (Table 1 and Fig. 4). Additionally, there was a negative linear relationship with trembling aspen $\mathrm{E}_{\mathrm{c}}$ with soil moisture (Fig 4a).

\subsection{4. ${ }^{13} \mathrm{C}$ and Ring growth}

Overall mean annual levels of $\Delta{ }^{13} \mathrm{C}$ were higher (more enriched) in trembling aspen than red maple indicating higher WUE for trembling aspen (Fig. 5a). 
Trembling aspen had higher $\Delta{ }^{13} \mathrm{C}$ across all years, independent of PDSI (Fig. 6a; no significant species x PDSI interaction). Also, trembling aspen had higher rates of mean growth over the study compared to red maple (Fig. 5b). Additionally, trembling aspen had higher growth rates than maple, with a significant effect from PDSI and a PDSI x species interaction (Fig. 6b). Trembling aspen exhibited a linear decrease of growth with increasing PDSI (Fig. 6b). PDSI did not affect $\Delta{ }^{13} \mathrm{C}$, but there was an effect of PDSI on growth rates (Fig. 6b).

\subsection{Discussion}

\subsubsection{Interspecific differences in transpiration}

Our data supported our first hypothesis in that trembling aspen had higher rates of daily transpiration than red maple during all years of the study; $J_{\mathrm{s}}$ and $\mathrm{E}_{\mathrm{c}}$ were significantly larger in aspen than red maple in all years of study (Fig. 3). A study in northern Wisconsin found aspen stomatal conductance to be twice that of sugar maple (Loranty et al. 2010). The study showed a doubling of the maximum range of stomatal conductance between trembling aspen and sugar maple (Loranty et al. 2010). Our study results shared a similar trend at the stand level with a doubling from maple to aspen Ec (Fig 3b).

Overall, the red maple trees in our study site were transpiring $1.5-2.3 \mathrm{~mm}$

day $^{-1}$, while the trembling aspen trees in our study were transpiring 3.9-4.8 mm day ${ }^{-1}$ 
at the stand level. A boreal study found a similar range of $1-7 \mathrm{~mm}^{-1 a y}{ }^{-1}$ sap flux in trembling aspen (Bernier et al. 2006). Additionally, a study in Tennessee also found an average transpiration rate of $1.5 \mathrm{~mm} \mathrm{day}^{-1}$ in mature red maple stand (Wullschleger et al. 2000).

\subsubsection{Effects of environmental variables on transpiration}

Our second hypothesis, that aspen transpiration would be less sensitive than that in maple to changes in soil moisture, was rejected in that there was no significant relationship between transpiration in red maple with soil moisture; however, there was a significant relationship between soil moisture and transpiration in trembling aspen (Table 1 and Fig. 4). It seems that overall, trembling aspen was found to be more sensitive to $\mathrm{PPFD}_{\text {int }}$ and soil moisture (Table 1). While red maple showed very little variability explained by either variable, the trees were more responsive to VPD (Table 1). This is similar to a trembling aspen-sugar maple study, which found that sugar maple was more influenced by changes in VPD than that of trembling aspen (Traver et al. 2010). Additionally, a boreal forest sap flux study found that vapor pressure deficit (VPD) did not affect carbon gain and water use in an trembling aspen stand (Hogg et al. 2000). However, during the study period the site received more precipitation than the stand transpired. Aspen productivity was greatly reduced during periods of low soil available water (Hogg and Hurdle 1995). Another study found that trembling aspen decreased canopy transpiration rates due to a decrease in growing season precipitation (Ewers et al. 2007). Additionally, our results are similar 
to a red maple study which found a high correlation in mean daily diurnal transpiration with VPD using heat pulse method sensors (Bowden and Bauerle 2008). Moisture excess could have been responsible for the negative trend of trembling aspen transpiration with soil moisture. Trembling aspen has been shown to have upper limitation to soil moisture, which may have caused, however unlikely, an unfavorable anaerobic soil environment that slowed transpiration rates (Traver et al. 2010, Aroca et al. 2012).

\subsubsection{Interannual variability and growth}

Our third hypothesis that trembling aspen would have higher rates of annual growth than red maple was supported during our study. Annual radial growth was greater in the trembling aspen trees than in the red maple trees across all years measured (Fig. 5b). This is similar to a study which found slow growth rates of red maple seedlings and high death rates due to sun intolerance (Palik and Pregitzer 1992). However, red maple grows denser than aspen, resulting in more biomass. Additionally, aspen has been shown to outcompete other shade tolerant understory species by having high growth rates in high light environments, due to high photosynthetic capacity (Kaelke et al. 2001). Trembling aspen growth showed a negative relationship with PDSI, which was similar to its relationship with stand level transpiration and soil moisture (Figs. 4a and 6b). This was likely a result of aspen's soil moisture threshold on the more saturated end of the PDSI range. One study 
suggests that when aspen are exposed to excessive soil moisture tree growth can be limited (Loranty et al. 2008).

\subsubsection{Water use efficiency}

Our final hypothesis that trembling aspen would have higher rates of annual WUE compared to maple, because it would be less susceptible to alterations in its environment, was partially supported by our study. Trembling aspen did have overall

higher ratio of ${ }^{13} \mathrm{C}:{ }^{12} \mathrm{C}$ (Fig. 5a). A higher ratio of ${ }^{13} \mathrm{C}:{ }^{12} \mathrm{C}$ in aspen indicated a higher rate of WUE, compared to red maple. However, it was more influenced by soil moisture and $\mathrm{PPFD}_{\text {int }}$ than red maple (Table 1). Palmer Drought Severity Index (PDSI) did not have a significant effect on WUE in either species (Fig. 6a).

However, the ability to photosynthesize during periods of increased temperature and decreased soil available water is likely why aspen had higher water use efficiency when compared to maple. An aspen study found that during periods of drought aspen had high levels of WUE compared to wet years (Krishnan et al. 2006). Trembling aspen was likely able to gain carbon at much higher rates than red maple in order to compensate for water losses during significantly higher transpiration rates (Fig. 3). Additionally, high WUE of aspen may have led to higher C gain in drier years (Fig. 6a). Aspen's high photosynthetic capacity in addition to our findings of high rates of transpiration can effectively make it both a productive and efficient tree species (Kaelke et al. 2001). 


\subsection{Conclusions}

Overall, this study showed a significant difference in transpiration rates between trembling aspen and red maple. Trembling aspen showed higher rates of transpiration at every scale in each year of study when compared to red maple. Trembling aspen transpiration was influenced by both soil moisture and solar radiation, while red maple was primarily influenced by VPD. Additionally, using dendrochronology it was found that trembling aspen had higher rates of growth and WUE than red maple. High levels of soil moisture and PDSI both reduced trembling aspen transpiration and growth, which was unexpected. Climate change is expected to increase annual mean temperature and precipitation in the Midwestern United States (Kirtman et al. 2013, Kunkel 2013, Pryor et al. 2014). Droughts are also likely to become more frequent in the future (Knapp et al. 2008). Our study indicates that trembling aspen had higher rates of growth and transpiration in drier conditions, pending high radiation levels, over red maple. This could indicate that trembling aspen may not respond as unfavorably to climate change as expected. However, it is been documented that aspen dieback was correlated with reduced growth caused by several years of low PDSI (Hanna and Kulakowski 2012). Climate change induced drought could affect trembling aspen more than red maple as indicated by our correlations with volumetric soil water content by each species. Stand composition may change in favor of red maple due to an increase of aspen dieback and natural death, caused in part by drought (He et al. 2013). A reduction of aspen productivity and growth would allow red maple to use excess available soil moisture and increase 
its range with the current mixed maple-aspen forests in the Midwestern United States.

However, our data suggests that trembling aspen may not be as affected by climate change in northern Minnesota as much as in its southern species range. 


\subsection{Tables and Figures}

Table 3.1. Partial $R^{2}$ analysis for relationships between stand sap flow $\left(E_{c}, m m\right.$ day $\left.^{-1}\right)$ and daily vapor pressure deficit (vpd), volumetric soil moisture (vwc), and total daily photosynthetically active photon flux density (ppfd). Intercepts, slopes coefficients, and $\mathrm{R}^{2}$ values are displayed for the linear regressions. Full model consists of combination of three independent variables. Partial $\mathrm{R}^{2}$ for adding covariate to model that already contains covariates y and z. $* p<0.05$, ** $p<0.01, * * * p<0.001, \mathrm{NS}=$ nonsignificant.

\begin{tabular}{lllll}
\hline Red & $\begin{array}{l}\text { Daily } \\
\text { soil } \\
\text { moisture } \\
\text { content } \\
\text { only }\end{array}$ & $\begin{array}{l}\text { Total } \\
\text { daytime } \\
\text { PPFD } \\
\text { only }\end{array}$ & Mean daily & Full model \\
\hline$\beta_{0}$ & $2.21^{* * *}$ & $1.91^{* * *}$ & $1.82^{* * *}$ & $1.93 * * *$ \\
$\beta_{1}$ & -1.55 & 0.008 & $0.37 * * *$ & $-0.45(\mathrm{vwc})$ \\
& & & & $-.003(\mathrm{ppfd})$ \\
$\mathrm{R}^{2}$ & 0.012 & 0.013 & 0.069 & $0.39(\mathrm{vpd})^{* *}$ \\
$\begin{array}{l}\text { Partial } \\
\mathrm{R}^{2} \text { for } \\
\text { adding }\end{array}$ & 0.0007 & 0.005 & 0.04 & 0.07 \\
\end{tabular}


Table 3.1. continued.

\begin{tabular}{|c|c|c|c|c|}
\hline $\begin{array}{l}\text { Trembling } \\
\text { aspen }\end{array}$ & $\begin{array}{l}\text { Daily } \\
\text { soil } \\
\text { moisture } \\
\text { content } \\
\text { only }\end{array}$ & $\begin{array}{l}\text { Total } \\
\text { daytime } \\
\text { PPFD } \\
\text { only }\end{array}$ & $\begin{array}{l}\text { Mean daily } \\
\text { VPD only }\end{array}$ & Full model \\
\hline$\beta_{0}$ & $6.22^{\star \star \star}$ & $2.16^{\star \star \star}$ & $3.14 * * *$ & $4.11 * * *$ \\
\hline$\beta_{1}$ & $-17.3 * * *$ & $0.12^{\star * *}$ & $2.09 * * *$ & $\begin{array}{l}-22.2(\mathrm{vwc})^{* * *} \\
0.16(\mathrm{ppfd})^{* * *} \\
-0.71(\mathrm{vpd})\end{array}$ \\
\hline $\mathrm{R}^{2}$ & 0.11 & 0.26 & 0.16 & 0.41 \\
\hline $\begin{array}{l}\text { Partial } R^{2} \\
\text { for adding }\end{array}$ & 0.14 & 0.21 & 0.009 & - \\
\hline
\end{tabular}



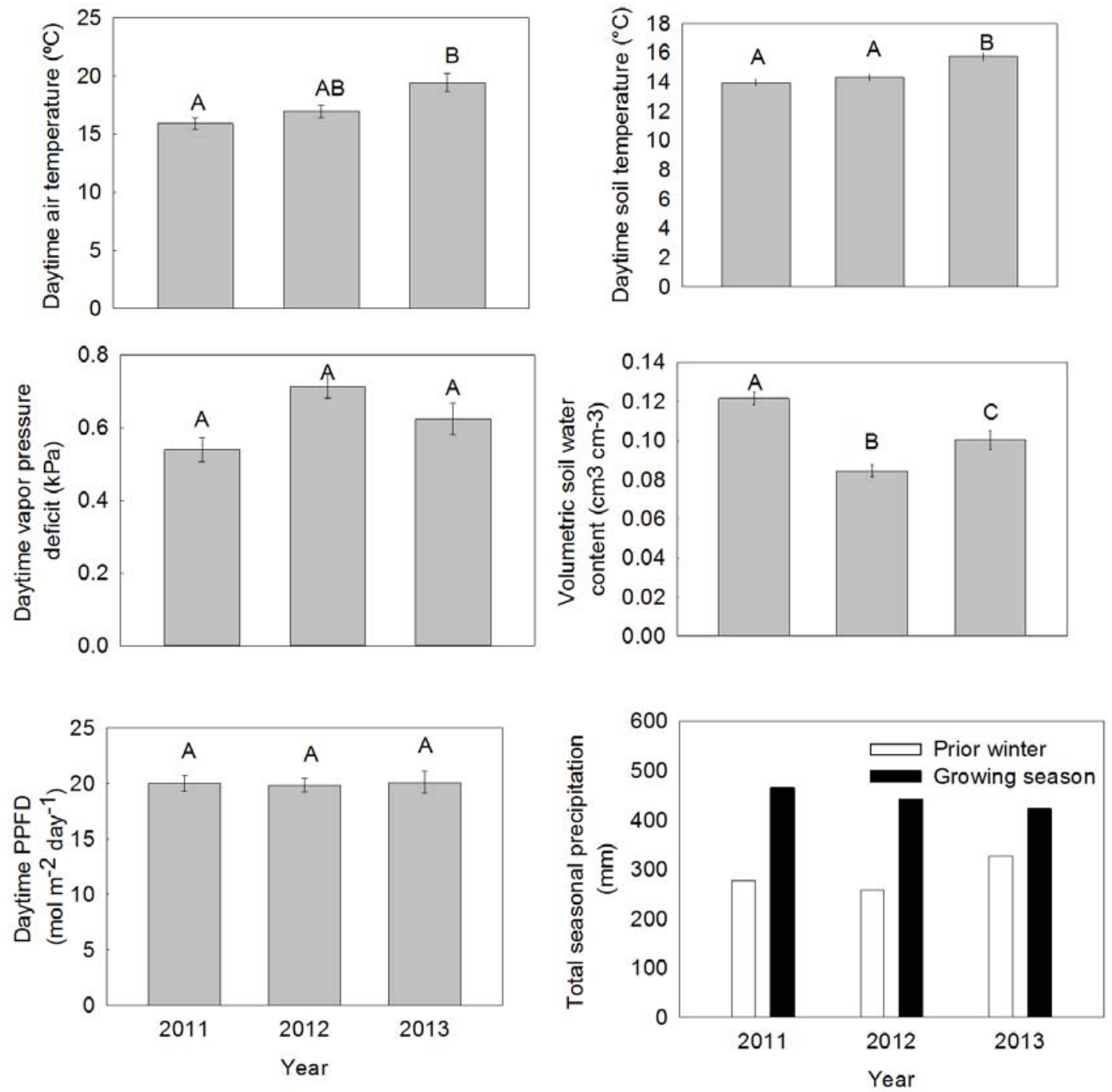

Figure 3.1. a) Growing season (May-Oct) mean daily daytime air temperature, b) soil temperature, c) vapor pressure deficit, d) volumetric soil moisture, e) PPFD, and f) total winter (Nov- Oct) and growing season precipitation during the period 20102013. Capital letters indicate significant difference between years. 

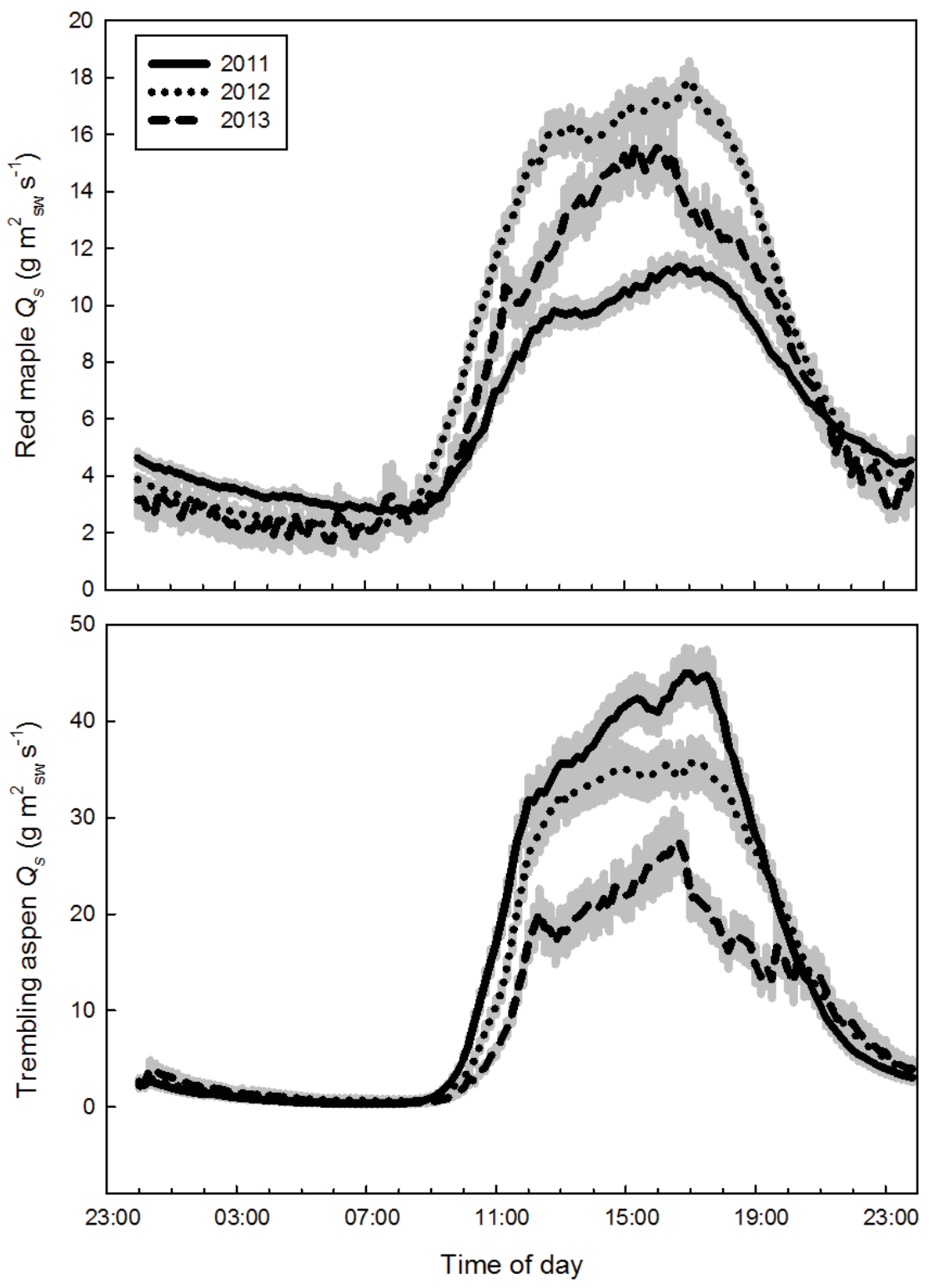

Figure 3.2. a) Red maple and b) trembling aspen mean diurnal tree level sap flux per unit sapwood area during the 2011-2013 growing seasons (May-October). Grey shading indicates one standard error of the mean. 

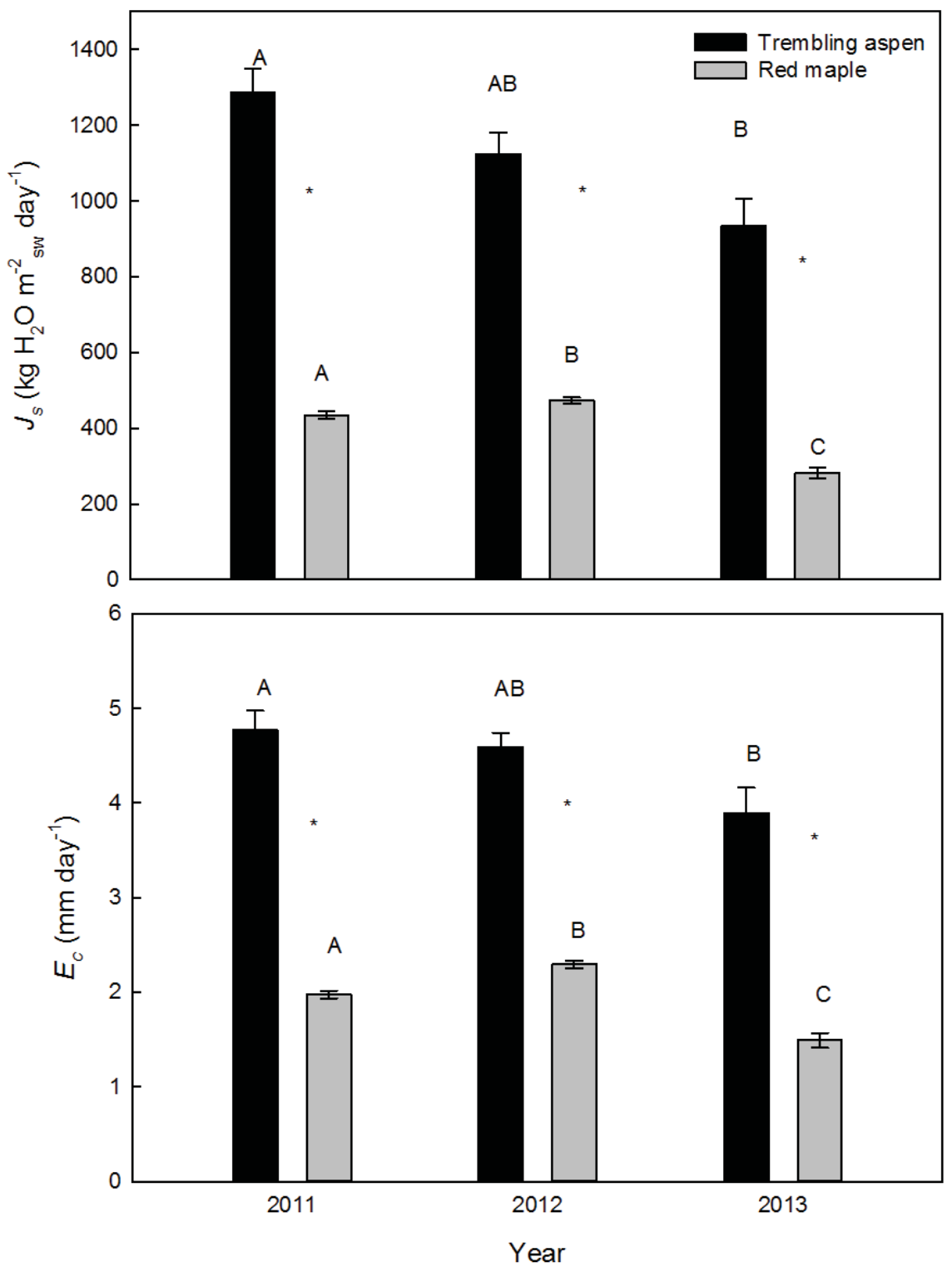

Figure 3.3. a) Mean daily $J_{s}$ and b) $E_{c}$ between aspen and red maple the 2011-2013 growing seasons (May-October). Error bars are one standard error of the mean. Capital letters indicate Tukey HSD posthoc within species between years; asterisks indicate significant difference between species within years. 

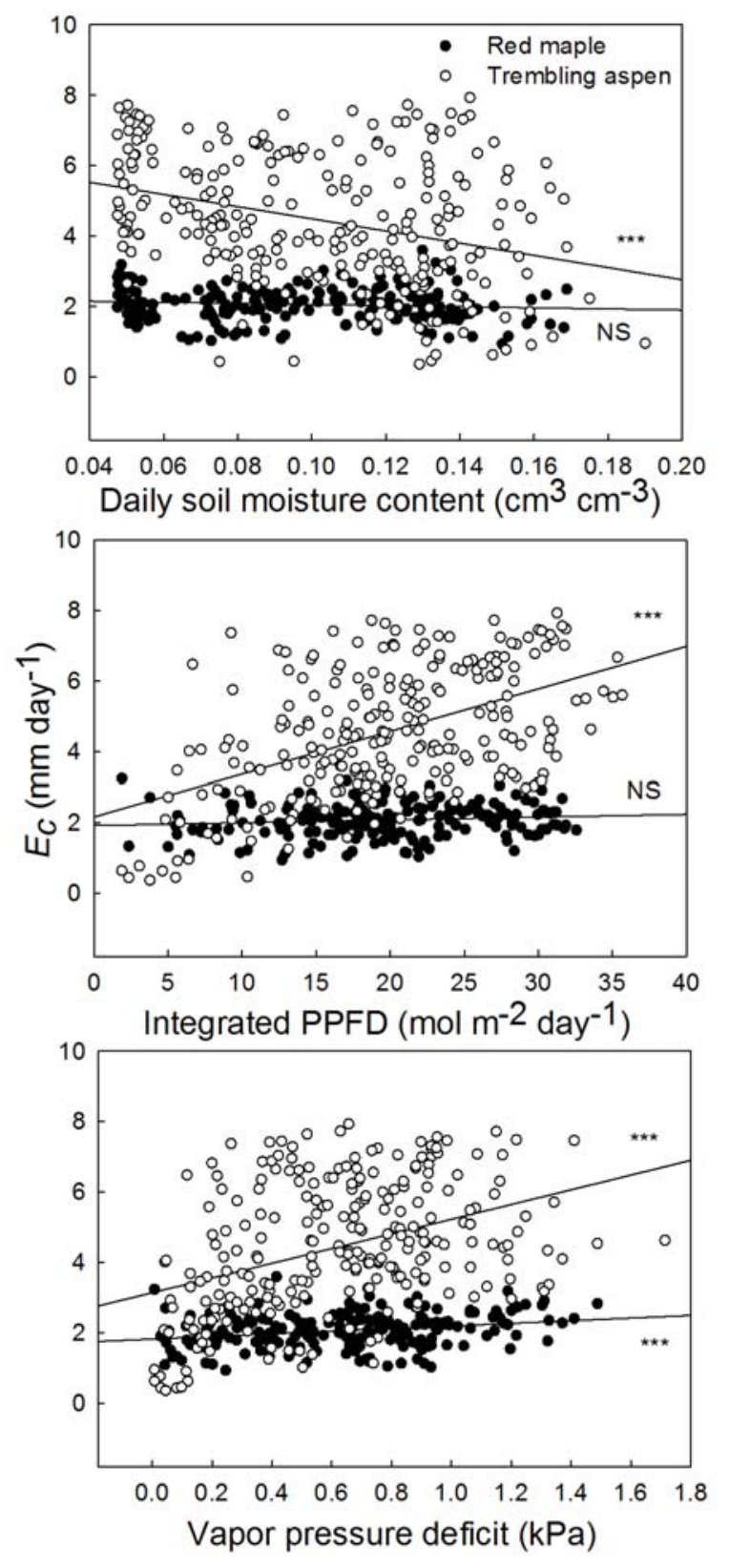

Figure 3.4. Relationships by species between daily Ec and a) volumetric soil moisture, b) daily integrated daylight, and c) daytime VPD. Asterisks indicate significance between Ec and variable. 

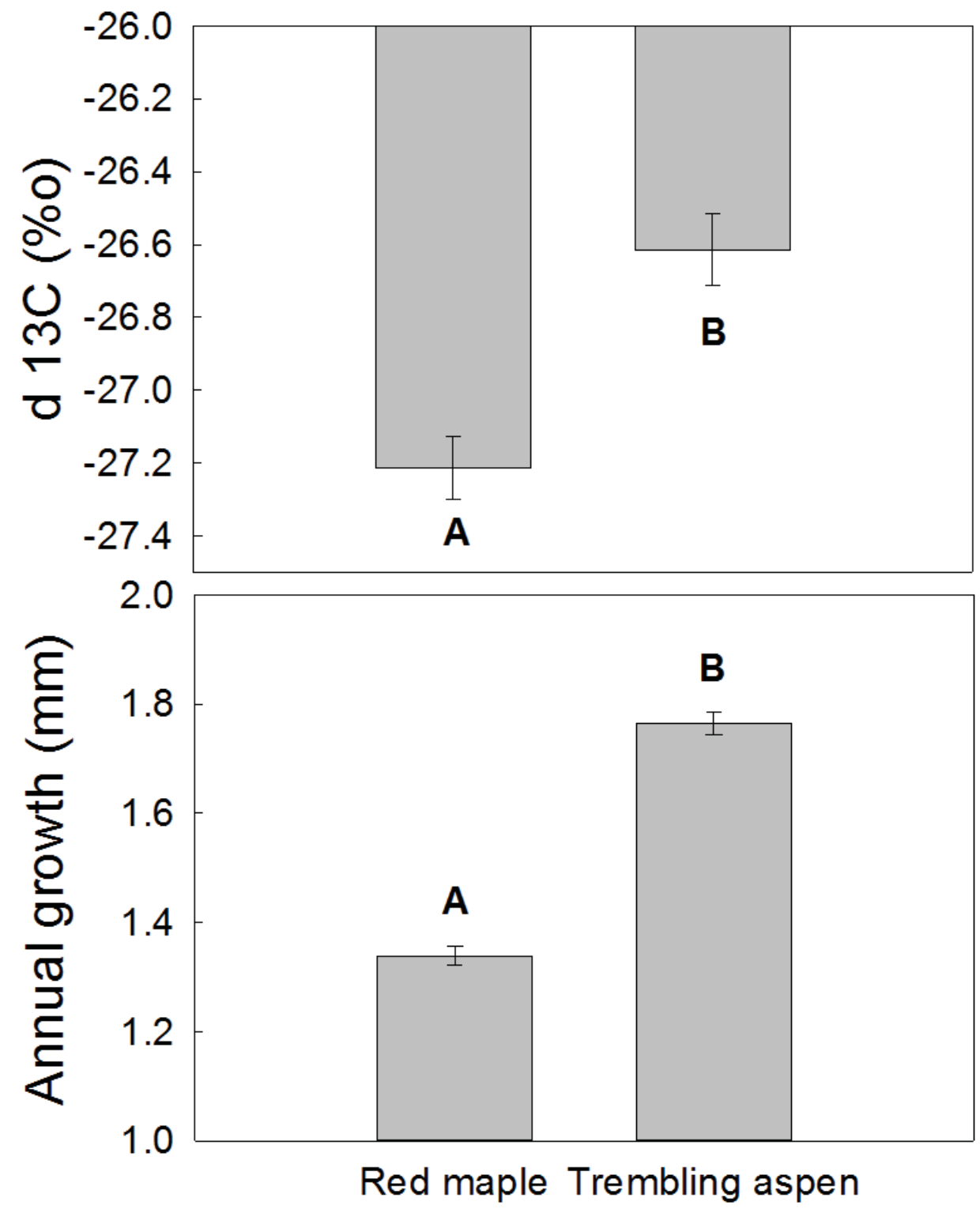

Figure 3.5. a) Annual ${ }^{13} \mathrm{C}$ and b) mean annual growth between red maple and trembling aspen during the 2001-2010 growing seasons. Error bars are one standard error of the mean. Letters indicate significant difference between species. 

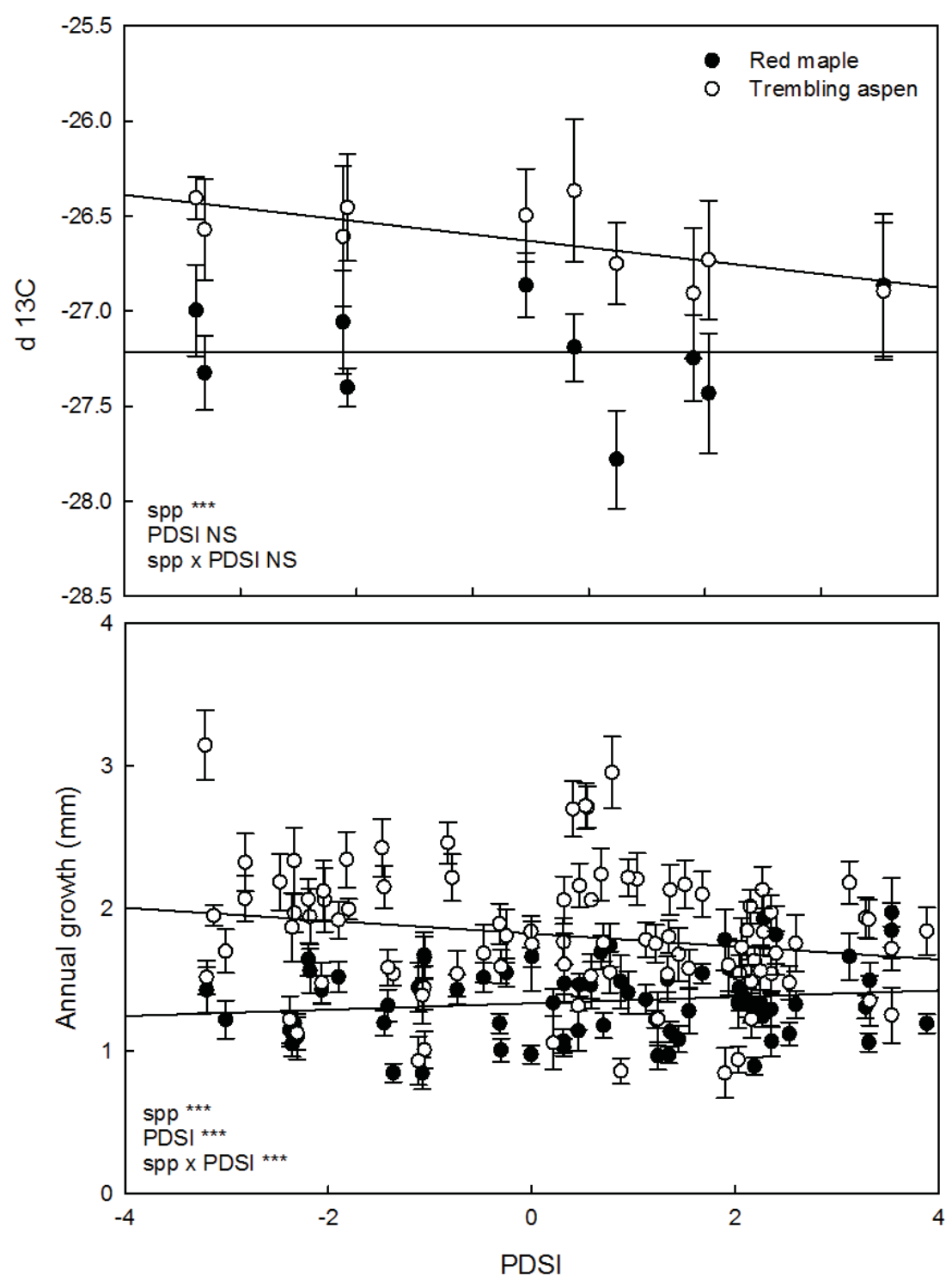

"Wetter"

Figure 3.6. Relationships by species between annual mean growing season Palmer Drought Severity Index (PDSI) and a) Annual ${ }^{13} \mathrm{C}$ and b) mean annual growth. Error bars are one standard error of the mean. Asterisks indicate significance between variables. 


\subsection{References}

Aroca, R., R. Porcel, J. M. Ruiz-Lozano, and J. Ruiz Lozano. 2012. Regulation of root water uptake under abiotic stress conditions. Journal of experimental botany 63:43-57.

Auclair, A. N. D., W. E. Heilman, and B. Brinkman. 2010. Predicting forest dieback in Maine, USA: a simple model based on soil frost and drought. Canadian Journal of Forest Research-Revue Canadienne De Recherche Forestiere 40:687-702.

Barton, A. M. and S. K. Gleeson. 1996. Ecophysiology of seedlings of oaks and red maple across a topographic gradient in eastern Kentucky. Forest Science 42:335-342.

Bernier, P. Y., P. Bartlett, T. A. Black, A. Barr, and N. Kljun. 2006. Drought constraints on transpiration and canopy conductance in mature aspen and jack pine stands. Agricultural and forest meteorology 140:64-78.

Bowden, J. and W. Bauerle. 2008. Measuring and modeling the variation in speciesspecific transpiration in temperate deciduous hardwoods. Tree Physiology 28:1675-1683.

Campbell, G. S. and J. M. Norman. 1998. An Introduction to Environmental Biophysics. 2nd edition. Springer, New York, NY.

Chen, J. 2011. The Physiology and Stability of Leaf Carbon Isotope Discrimination as a Measure of Water-Use Efficiency in Barley on the Canadian Prairies. Journal of agronomy and crop science 197:1-11. 
Christensen, J. H., B. Hewitson, A. Busuioc, A. Chen, X. Gao, I. Held, R. Jones, R.K. Kolli, W.T. Kwon, R. Laprise, V.M. Rueda, L. Mearns, C.G. Menéndez, J. Räisänen, A. Rinke, A. Sarr, and P. Whetton., editors. 2007. Regional Climate Projections: Climate Change 2007: The Physical Science Basis. Contribution of Working Group I to the Fourth Assessment Report of the Intergovernmental Panel on Climate Change. Cambridge University Press, Cambridge, New York.

Cooke, B. J. and J. Roland. 2007. Trembling aspen responses to drought and defoliation by forest tent caterpillar and reconstruction of recent outbreaks in Ontario. Canadian Journal of Forest Research-Revue Canadienne De Recherche Forestiere 37:1586-1598.

Dai, A. 2010. Drought under global warming: A review. Wiley Interdisciplinary Reviews: Climate Change 2:45-65.

Eglin, T., F. Maunoury-Danger, C. Fresneau, C. Lelarge, B. Pollet, C. Lapierre, C. Francois, and C. Damesin. 2008. Biochemical composition is not the main factor influencing variability in carbon isotope composition of tree rings. Tree Physiology 28:1619-1628.

Ewers, B. E., D. S. Mackay, and S. Samanta. 2007. Interannual consistency in canopy stomatal conductance control of leaf water potential across seven tree species. Tree Physiology 27:11-24.

Farquhar, G. D. 1989. Carbon isotope discrimination and photosynthesis. Annual review of plant physiology 40:503-537. 
Frey, B. R., V. J. Lieffers, E. H. Hogg, and S. M. Landhausser. 2004. Predicting landscape patterns of aspen dieback: mechanisms and knowledge gaps. Canadian Journal of Forest Research-Revue Canadienne De Recherche Forestiere 34:1379-1390.

Gebauer, T., V. Horna, and C. Leuschner. 2008. Variability in radial sap flux density patterns and sapwood area among seven co-occurring temperate broad-leaved tree species. Tree Physiology 28:1821-1830.

Granier, A. 1985. A new method of sap flow measurement in tree stems. Annales des sciences forestières 42:193-200.

Granier, A. 1987. Evaluation of transpiration in a douglas-fir stand by means of sap flow measurements. Tree Physiology 3:309-319.

Grission-Mayer, H. D. 2001. Evaluating crossdating accuracy: a manual and tutorial for the computer program COFECHA. Tree Ring Research 57:205-221.

Hanna, P. and D. Kulakowski. 2012. The influences of climate on aspen dieback. Forest ecology and management 274:91-98.

He, J. S., Q. B. Zhang, and F. A. Bazzaz. 2005. Differential drought responses between saplings and adult trees in four co-occurring species of New England. Trees-Structure and Function 19:442-450.

He, L., V. Ivanov, G. Bohrer, J. Thomsen, and C. Vogel. 2013. Temporal dynamics of soil moisture in a northern temperate mixed successional forest after a prescribed intermediate disturbance. Agricultural and forest meteorology 180:22-33. 
Hogg, E. H. and P. A. Hurdle. 1995. The aspen parkland in western canada- A dryclimate analog for the future boreal forest. Water Air and Soil Pollution 82:391-400.

Hogg, E. H., B. Saugier, J. Y. Pontailler, T. A. Black, W. Chen, P. A. Hurdle, and A. Wu. 2000. Responses of trembling aspen and hazelnut to vapor pressure deficit in a boreal deciduous forest. Tree Physiology 20:725-734.

Iverson, L., A. Prasad, S. Matthews, and M. Peters. 2008. Estimating potential habitat for 134 eastern US tree species under six climate scenarios. Forest ecology and management 254:390-406.

James, S. A., M. J. Clearwater, F. C. Meinzer, and G. Goldstein. 2002. Heat dissipation sensors of variable length for the measurement of sap flow in trees with deep sapwood. Tree Physiology 22:277-283.

Kaelke, C. M., E. L. Kruger, and P. B. Reich. 2001. Trade-offs in seedling survival, growth, and physiology among hardwood species of contrasting successional status along a light-availability gradient. Canadian journal of forest research 31:1602-1616.

Kagawa, A., L. Sack, K. e. Duarte, and S. James. 2009. Hawaiian native forest conserves water relative to timber plantation: Species and stand traits influence water use. Ecological Applications 19:1429-1443.

Kirtman, B., S. B. Power, J. A. Adedoyin, G. J. Boer, R. Bojariu, I. Camilloni, F. J. Doblas-Reyes, A. M. Fiore, M. Kimoto, G. A. Meehl, M. Prather, A. Sarr, C. Schär, R. Sutton, G. J. van Oldenborgh, G. Vecchi, and W. H.J. 2013. Near- 
term Climate Change: Projections and Predictability. Pages 953-1028 in T. F. Stocker, D. Qin, G.-K. Plattner, M. Tignor, S. K. Allen, J. Boschung, A. Nauels, Y. Xia, V. Bex, and P. M. Midgley, editors. Climate Change 2013: The Physical Science Basis. Contribution of Working Group I to the Fifth Assessment Report of the Intergovernmental Panel on Climate Change. Cambridge University Press, Cambridge, United Kingdom and New York, NY, USA.

Knapp, A., C. Beier, D. Briske, A. Classen, and Y. Luo. 2008. Consequences of More Extreme Precipitation Regimes for Terrestrial Ecosystems. BioScience 58:811-821.

Krishnan, P., T. A. Black, N. Grant, and A. Barr. 2006. Impact of changing soil moisture distribution on net ecosystem productivity of a boreal aspen forest during and following drought. Agricultural and forest meteorology 139:208223.

Kunkel, K. E., L.E. Stevens, S.E. Stevens, L. Sun, E. Janssen, D. Wuebbles, S.D. Hilberg, M.S. Timlin, L. Stoecker, N.E. Westcott, and J.G. Dobson. 2013. Part 3. Climate of the Midwest U.S. Page 96 NOAA Technical Report NESDIS $142-3$.

Loranty, M., D. S. Mackay, B. Ewers, J. Adelman, and E. Kruger. 2008. Environmental drivers of spatial variation in whole-tree transpiration in an aspen-dominated upland-to-wetland forest gradient. Water resources research 44. 
Loranty, M., D. S. Mackay, B. Ewers, E. Traver, and E. Kruger. 2010. Contribution of competition for light to within-species variability in stomatal conductance. Water resources research $\mathbf{4 6}$.

Lu, P., L. Urban, and P. Zhao. 2004. Granier's thermal dissipation probe (TDP) method for measuring sap flow in trees: Theory and practice. Acta Botanica Sinica 46:631-646.

Niinemets, U. and F. Valladares. 2006. Tolerance to shade, drought, and waterlogging of temperate Northern Hemisphere trees and shrubs. Ecological Monographs 76:521-547.

Palik, B. J. and K. S. Pregitzer. 1992. The age and height structur of red maple (acerrubrum) population in northern micigan bigtooth aspen (populusgrandidentata) forests. Canadian Journal of Forest Research-Revue Canadienne De Recherche Forestiere 22:1449-1462.

Perala, D. A. 1990. Populus tremuloides Michx. quaking aspen. Aspen Bibliography:Paper 2878.

Ponton, S., J. L. Dupouey, N. Breda, F. Feuillat, C. Bodenes, and E. Dreyer. 2001. Carbon isotope discrimination and wood anatomy variations in mixed stands of Quercus robur and Quercus petraea. Plant Cell and Environment 24:861868.

Poorter, L. 2009. Leaf traits show different relationships with shade tolerance in moist versus dry tropical forests. New Phytologist 181:890-900. 
Prasad, A. M., L. R. Iverson, S. Matthews, and M. Peters. 2014. A Climate Change Atlas for 134 Forest Tree Species of the Eastern United States [database]. http://www.nrs.fs.fed.us/atlas/tree, Northern Research Station, USDA Forest Service. Delaware, Ohio.

Pryor, S. C., D. Scavia, C. Downer, M. Gaden, L. Iverson, R. Nordstrom, J. Patz, and G. P. Robertson. 2014. Ch. 18 Mid-West. Climate Change Impacts in the United States: The Third National Climate Assessment.

Rozas, V. 2003. Tree age estimates in Fagus sylvatica and Quercus robur: testing previous and improved methods. Plant Ecology 167:193-212.

Sebestyen, S. D., C. Dorrance, D. M. Olson, E. S. Verry, R. K. Kolka, A. E. Elling, and R. Kyllander, editors. 2011. Long-term monitoring sites and trends at the Marcell Experimental Forest. Chapter 2. CRC Press, Boca Raton, FL.

Tang, J., P. Bolstad, B. Ewers, A. Desai, and K. Davis. 2006. Sap flux-upscaled canopy transpiration, stomatal conductance, and water use efficiency in an old growth forest in the Great Lakes region of the United States. Journal of geophysical research 111.

Tong, X. 2014. Ecosystem water use efficiency in a warm-temperate mixed plantation in the North China. Journal of hydrology 512:221-228.

Traver, E., B. Ewers, D. Mackay, and M. Loranty. 2010. Tree transpiration varies spatially in response to atmospheric but not edaphic conditions. Functional ecology 24:273-282. 
USDA Forest Service. 2004. Crowns: measurement and sampling. USDA Forest Service, Arlington, VA.

Verry, E. S. and A. E. Elling, editors. 2011. Marcell Experimetnal Forest cumulative hydrology database, 1960-2011. St. Paul, MN: U.S. Department of Agriculture, Forest Service, North Central Research Station. RDS-NC-43512005-001.

Walters, R. S. and H. W. Yawney. 1990. Acer rubrum L.: red maple. USDA For. Serv. Agric. Handb. 654. p. 60-69.

Wullschleger, S. D., K. B. Wilson, and P. J. Hanson. 2000. Environmental control of whole-plant transpiration, canopy conductance and estimates of the decoupling coefficient for large red maple trees. Agricultural and forest meteorology 104:157-168.

Zhang, J. W., Z. Feng, B. M. Cregg, and C. M. Schumann. 1997. Carbon isotopic composition, gas exchange, and growth of three populations of ponderosa pine differing in drought tolerance. Tree Physiology 17:461-466. 


\section{Investigating the potential wounding response of two}

\section{northern hardwood species to long term use of sap flux heat} dissipation sensors ${ }^{3}$

\subsection{Abstract}

Heat dissipation sensors have been used for decades as a method to determine the rate of xylem sap flux in trees. The sensors can experience malfunction due to short circuiting, water damage, animal damage, and deterioration over time. Error due to physiological wounding response can also affect data from season to season. Our overall study objectives were to investigate the effects of wounding response over time on the consistency over a three year period of sap flux estimates in heat dissipation sensors in two northern hardwood species in Michigan and Minnesota and to create a correction factor to account for wounding effect. The difference in sap flux rates was measured between the older, previously installed sap flux sensors and newly installed sensors, both installed at the same depth of sapwood. As expected, sapflux density $\left(\mathrm{Q}_{\mathrm{s}}\right)$ was greater in newly installed sensors than in two-year old sensors in all species, with the greatest discrepancy between old and new probes occurring midday (1-3pm). The wounding effect on total daily sapflux (J) was greatest in trembling aspen (40\%) and smallest in sugar maple (9\%). The large difference in aspen was likely as result of tyloses forming in the wound site.

\footnotetext{
${ }^{3}$ This chapter is in preparation for submission to the peer-reviewed journal Tree Physiology.
} 
Wounding effects caused an underestimation in sap flux data in sugar maple and trembling aspen for older sensors. Adjustment for wounding year to year will be necessary in any sap flux study over long periods of time to compensate for underestimation of sap flux measurements.

\subsection{Introduction}

Heat dissipation sensors have been used for decades as a method to determine the rate of xylem sap flux in trees (Granier 1985, 1987). Sap flux density $\left(\mathrm{Q}_{\mathrm{s}}\right)$ is calculated by comparing a constantly heated thermocouple with a non-heated reference thermocouple (Granier 1987). The temperature differential between the two thermocouples dictates the rate of $\mathrm{Q}_{\mathrm{s}}$. Over time, heat dissipation sensors are prone to malfunction due to short circuiting, water damage, animal damage, and deterioration (David et al. 2004). Error due to xylem tissue physiological wounding response, in addition to sensor malfunction, can also affect data from season to season (Moore et al. 2010).

The process of sensor installation requires drilling into the conducting xylem tissue (i.e., sapwood) to create a pore for the sensor to be placed. The heat dissipation sap flow sensor wound, which has been shown to cut tracheids and vessels in Douglas fir and red alder, could lead to embolism which would break the water column within the xylem (Moore et al. 2010). The embolism could lead to the water column being 
rerouted around the wound site in an attempt to maintain hydraulic continuity. The disruption of the water column would inevitably cause a change in $\mathrm{Q}_{\mathrm{s}}$ rates near the wound site. For example, a study in New Zealand found a $10 \%$ error in estimates when comparing heat pulse sap flux measurements of mountain beech to weighing lysimetry (Swanson and Whitfield 1981). Radial wood growth around the sensors could also lead to misleading data over time. Wood growth could cause sensors to be embedded beyond the newest sapwood and produce inaccurate data (Moore et al. 2010).

The area of affected tissue affected by a wound can also vary by species (Frankenstein et al. 2006). For example, tyloses, the outgrowth of parenchyma cells, develop after wounding to alter water and mineral transpiration in xylem vessels (Zhao 2014). Also, the compartmentalization of plasma membrane can occur in the event of a wound to separate affected areas to minimize damaged cells (Urbanus and Ott 2012). This division of the plasma membrane lead to callus tissue formation in order to close the wound site (Biggs 1992). Suberin, a waxy water-proofing substance, has been found to aid in healing the effects of wounding (Biggs 1997). Understanding the species-specific responses of northern hardwoods to wounding will allow us to be able to correct for this potential source of error.

Our overall study objectives were to investigate the effects and wounding response over time on the consistency of sap flux estimates in heat dissipation sensors in two northern hardwood species in Michigan and Minnesota and to create a 
correction factor for any sensor error. We hypothesized that: 1) Apparent sapflux density $\left(Q_{s}\right)$ and total daily sap flux $(J)$ would decrease after two years as a result of wounding response in both tree species, 2) the difference between old and new sensor $\mathrm{Q}_{\mathrm{s}}$ would be greatest at midday, when transpiration rates are highest, and 3) trembling aspen would exhibit greater differences in $\mathrm{J}$ between old and new sensors than sugar maple as a result of an increased wounding response.

\subsection{Materials and Methods}

\subsubsection{Overall study design}

This study simultaneously compared new and old heat dissipation sap flux sensors to aid in our understanding of how consistent sap flux sensors were over time with estimating sap flux rates in sugar maple and trembling aspen. We calculated the difference in measured sap flux rates between the older, previously installed sap flux sensors and newly installed sensors, both installed at the same depth of sapwood. In May 2013, new $1 \mathrm{~cm}$ deep sensors were installed in 43 sample trees, across two field sites and two species. Thirty-three sugar maple trees were instrumented at a site in Upper Peninsula Michigan, while ten trembling aspen trees were instrumented with

old and new sensors at a site in Northern Minnesota. New sensors simultaneously recorded data with 43 previously installed sensors from 2011. Each sensor recorded 
temperature differentials, which ultimately were converted to sap flux densities $\left(\mathrm{Q}_{\mathrm{s}} ; \mathrm{g}\right.$ $\left.\mathrm{m}^{-2} \mathrm{~s}^{-1}\right)$ and daily sap flux $\left(J ; \mathrm{kg} \mathrm{m}^{-2} \mathrm{day}^{-1}\right)$.

\subsubsection{Michigan site}

The first location was a sugar maple dominated stand located $13 \mathrm{~km}$ south of L'Anse, Michigan within the Ford Center and Forest of Michigan Technological University $\left(46^{\circ} 64^{\prime} \mathrm{N}, 88^{\circ} 48^{\prime} \mathrm{W}\right.$; . Sugar maple accounted for $89.3 \%\left(21.7 \mathrm{~m}^{2} \mathrm{ha}^{-1}\right)$ of the overstory basal area. American elm (Ulmus Americana L.), eastern hemlock (Tsuga canadensis L.), ironwood (Ostrya Virginia Mill.), and yellow birch (Betula alleghaniensis Britton) also occurred in the overstory. The mean annual temperature and precipitation were $4.9^{\circ} \mathrm{C}$, and $879 \mathrm{~mm}$, respectively. The soil was classified as Kallio silt loam (Jarvi and Burton 2013). The study was located on the Sugar Maple Altered Rainfall and Temperature experiment (SMART), which has been ongoing since 2010 (Jarvi and Burton 2013). The study had three replicates of four treatments: heat, heat+water, water, and control. A replicate consisted of a $10 \mathrm{~m} \times 10$ $\mathrm{m}$ plot with $5 \mathrm{~m}$ wide buffers. The heating increased soil temperature $4-5^{\circ} \mathrm{C}$ above ambient, while the heat+water added additional irrigation at a rate equivalent to $+30 \%$ ambient precipitation, to compensate for evaporative losses (see Jarvi and Burton 2013 for further details). Treatment effects were not assessed in this paper. 


\subsubsection{Minnesota site}

The second study location was a trembling aspen/ red maple stand located outside of Grand Rapids, Minnesota, within the USDA's Marcell Experimental Forest (MEF) $\left(47^{\circ} 32^{\prime} \mathrm{N}, 9^{\circ} 28^{\prime} \mathrm{W}\right)$. Trembling aspen (Populus tremuloides), bigtooth aspen ( $P$. grandidentata), balsam poplar (P. balsamifera), paper birch (Betula papyrifera), balsam fir (Abies balsamea), and red maple (Acer rubrum) dominated the canopy (Sebestyen et al. 2011). The mean annual temperature and precipitation were $3.4 \pm 13.0^{\circ} \mathrm{C}$ and $780.0 \pm 110.0 \mathrm{~mm}$, respectively (Sebestyen et al. 2011). The soils were sandy loams consisting of Menahga sand (mixed frigid Typic Udipsamments) and Graycalm loamy sands [(Isotic, frigid Lamellic Udipsamments (Sebestyen et al. 2011)]. Xylem sap flux was measured in an area encompassing $6000 \mathrm{~m}^{2}$, consisting of ten trembling aspen trees.

\subsubsection{Sap flux}

Sap flux was measured between mid- May and mid-October in 2013, using variable-length sap flux sensors (Granier 1985, 1987, James et al. 2002). Each sensor contained two copper-constantan thermocouple probes encased each in $1 \mathrm{~cm}$ aluminum tips. Each upper probe was heated, to create a temperature differential with the unheated probe. New probes were installed $10 \mathrm{~cm}$ apart vertically, staggered near breast height, and at least $90^{\circ}$ apart horizontally to prevent heating overlap with sensors from 2011. Reflective insulation (Reflectix, Inc., Markleville, IN) was used to prevent an external thermal gradient (Lu et al. 2004). Deep-cycle batteries (12 V, 105 
AH; model M2 and M3 Diehard, Sears, Hoffman Estates, IL) supplied power to the upper (heated) probes.

Voltage differentials (correlated with temperature differences) between probes in each sensor were measured every minute, and the average was logged every 10 minutes with a CR1000 datalogger and two 32 channel relay multiplexers (Campbell Scientific, Logan, UT). Voltages were converted to sap flux densities $\left(v ; \mathrm{g} \mathrm{m}^{-2} \mathrm{~s}^{-1}\right)$ based on Granier's empirical calibration method (Granier 1987, Gebauer et al. 2008):

$$
v=119 \times\left(\frac{\Delta V_{m}-\Delta V}{\Delta V}\right)^{1.231}
$$

where $\Delta V$ is the difference in voltage between the two thermocouples for each 10 minute interval and $\Delta V_{\mathrm{m}}$ is the daily maximum difference in voltage, corresponding to minimum daily sap flux density. Sap flux densities $\left(\mathrm{Q}_{\mathrm{s}}, \mathrm{g} \mathrm{m}^{-2} \mathrm{~s}^{-1}\right)$ were calculated using only single sensors for comparison purposes, and were not scaled to whole-tree rates. Daily sap flux per sensor $\left(\mathrm{J}_{\mathrm{s}} ; \mathrm{kg} \mathrm{m}^{-2} \mathrm{day}^{-1}\right)$ was created by summing the ten minute intervals of $\mathrm{Q}_{\mathrm{s}}$ for each 24 hour period.

\subsubsection{Data analysis}

Wounding response was calculated for each sensor pair as the difference between sap flux between the new (installed 2013) and old sensors (installed 2011) to find potential measurement bias. A repeated measures analysis of variance (ANOVA) 
was used to look at the difference between measured rates of $\mathrm{J}$ in current sensors versus two-year-old sensors in each species to test hypothesis 1. ANOVAs were also used to find the peak daily differences and time of $\mathrm{Q}_{\mathrm{s}}$ to test hypothesis 2. ANOVAs were also used to determine interspecific differences in wounding response for hypothesis 3 .

\subsection{Results}

Sapflux density $\left(Q_{s}\right)$ was greater in sensors installed in 2013 than in 2011 in all species (Fig. 1a and 1c). The mean peak difference in sugar maple $\mathrm{Q}_{\mathrm{s}}$ was found to be $2.03 \mathrm{~g} \mathrm{~m}_{\mathrm{sw}}^{-2} \mathrm{~s}^{-1}$ at approximately 18:10 hrs (Table 1 ). The mean peak difference in

trembling aspen $\mathrm{Q}_{\mathrm{s}}$ was found to be $5.90 \mathrm{~g} \mathrm{~m}_{\mathrm{sw}}^{-2} \mathrm{~s}^{-1}$ at approximately 16:40 hrs (Table 1). Measured $Q_{s}$ was $6 \%$ greater in new sensors than in two-year-old sensors in sugar maple and 36\% greater in trembling aspen (Fig. 1a and 1c). The absolute difference in $\mathrm{Q}_{\mathrm{s}}$ between sensors from 2013 and 2011 showed the greatest difference in the afternoon in sugar maple and trembling aspen (Fig. 1b and 1d). Differences in total daily sapflux (J) between old and new sensors were significant for both sugar maple and trembling aspen (Fig. 2). Daily rates of sugar maple J were 9\% greater in new sensors, while rates measured by the newer sensors in trembling aspen were $40 \%$ greater (Table 1). Wounding effect of older sensors was greatest in trembling aspen and least in sugar maple (Fig. 2). 


\subsection{Discussion}

\subsubsection{Error due to sensor age for all species}

Overall, both species showed evidence of a wounding response as indicated by a difference in sap flux measurements between old and new sensors taking simultaneous measurements (Fig. 1). Also, the difference in J between sensor's installation dates, indicated a wounding response in trembling aspen and sugar maple (Fig 2). This supports our first hypothesis in that there was a wounding effect, causing a significant decrease in $\mathrm{J}$ between the two sensor ages.

Installation of sensors causes xylem damage regardless of tree species (Barrett et al. 1995). A thermal dissipation study found a decrease up to $45 \%$ in a Douglas fir between two growing seasons using the same sensors for each year of study (Moore et al. 2010). The study found that heat dissipation sensors to be susceptible to various errors if used for more than two field seasons (Moore et al. 2010). The site of sensor installation thus can cause a decrease in localized water movement due to internal wound healing processes within the tree. Overall, sensor installation causes alterations in the tree to heal wounds caused by sensors.

\subsubsection{Timing of sensor error}

The difference between sapflux density in sugar maple and trembling aspen supported our second hypothesis (Figure $1 \mathrm{~b}$ and $1 \mathrm{~d}$ ). There was a difference between the older and younger sensors measurements from the same growing season, 
which peaked at approximately 18:10 and 16:40 hrs for sugar maple and trembling aspen, respectively (Table 1). This likely was a result of peak transpiration due to high mid-day solar radiation levels (Tang et al. 2006).

\subsubsection{Wounding response differs across species}

Trembling aspen exhibited a greater wounding response in regards to $\mathrm{J}$ difference than sugar maple during the study, which supported our last hypothesis (Fig 2). A study by Schmitt and Liese (1993) found that rerouting of water column by suberization of the xylem parenchyma cells was dependent on species. The study found that when species of Fagus, Quercus, and Populus were mechanically wounded with a scalpel they released suberized tyloses (Schmitt and Liese 1993).

Another thermal dissipation study found vessels near the wounding site may be subject to the formation of tyloses, which prevent water movement near the wound (Wullschleger et al. 2011). Tyloses are a common type of vascular sealant, which form from parenchyma cells (Sun et al. 2008). Trembling aspen use tyloses to obstruct vessel elements after wounding (Crane et al. 1995). This area would then be unable to move water as effectively as before the wound occurred (Wullschleger et al. 2011). Trembling aspen was able to create tyloses unlike sugar maples, which made it capable of a greater wounding effect. Additionally, a study found that a Populus hybrid species would increase lignin content in the xylem when wounded with a saw and chisel, thus modifying cell walls and potentially increasing resistance against wounding through compartmentalization (Frankenstein et al. 2006). Also, it has been 
found in oak species that tyloses tend to block earlywood within a year of growth (Cochard and Tyree 1990). Trembling aspen was able to heal the site of sensor installation from 2011, which resulted in $40 \%$ lower estimation of $\mathrm{J}$.

Sugar maple also showed signs of wounding effects during the study. Japanese maple has been observed to compartmentalize wounds with callus and wound xylem to seal an injury in the xylem (Copini et al. 2014). The ability to seal the wounded area with a sealant would slow the rates of water movement in the region of xylem. The lower rate of difference in $\mathrm{J}$ in maple, compared to trembling aspen, may indicate a lower efficiency to reroute water after a wounding event.

\subsection{Conclusions}

Steps need to be taken to adjust for the inevitable loss of accuracy due to wounding and sensor age. Wounding effects caused an underestimation in sap flux data in sugar maple and trembling aspen over one field season. Installation of the sap flux sensors created wounds regardless of species. Peak differences in $\mathrm{Q}_{s}$ were greater in aspen over sugar maple, which may indicate a larger wounding response in aspen. The presence of tyloses in aspen may have been responsible for the larger difference in sap flux estimation between the old and new sensors in the study period. As a result, wound correction (Table 1) to adjust for error during installation is likely the best method to correct for transpiration underestimation (Swanson and Whitfield 
1981, Steppe et al. 2010). Adjustment year to year will be necessary in any sap flux study over long periods of time. 


\subsection{Tables and Figures}

Table 4.1. Species, sample sizes, number of days sampled, diameter at breast height range, mean $\mathrm{Q}_{\mathrm{s}}$, peak $\mathrm{Q}_{\mathrm{s}}$, time of peak $\mathrm{Q}_{\mathrm{s}}$, and $\mathrm{J}$ correction factor from study.

\begin{tabular}{lll}
\hline & Sugar maple & Trembling aspen \\
\hline $\mathrm{n}$ & 30 & 6 \\
\hline $\begin{array}{l}\text { Sample } \\
\text { days }\end{array}$ & 84 & 12 \\
\hline $\begin{array}{l}\text { Diameter } \\
\text { Range }(\mathrm{cm})\end{array}$ & $8-52$ & $30-45$ \\
\hline Mean $\mathrm{Q}_{\mathrm{s}}\left(\mathrm{g} \mathrm{m}_{\mathrm{sw}}^{-2} \mathrm{~s}^{-1}\right)$ & 0.62 & 2.16 \\
\hline Peak $\mathrm{Q}_{\mathrm{s}}\left(\mathrm{g} \mathrm{m}_{\mathrm{sw}} \mathrm{s}^{-1}\right)$ & 2.03 & 5.90 \\
\hline Time of peak $\mathrm{Q}(\mathrm{hrs})$ & $18: 10$ & $16: 40$ \\
\hline J correction factor $(\%)$ & 9 & 40
\end{tabular}



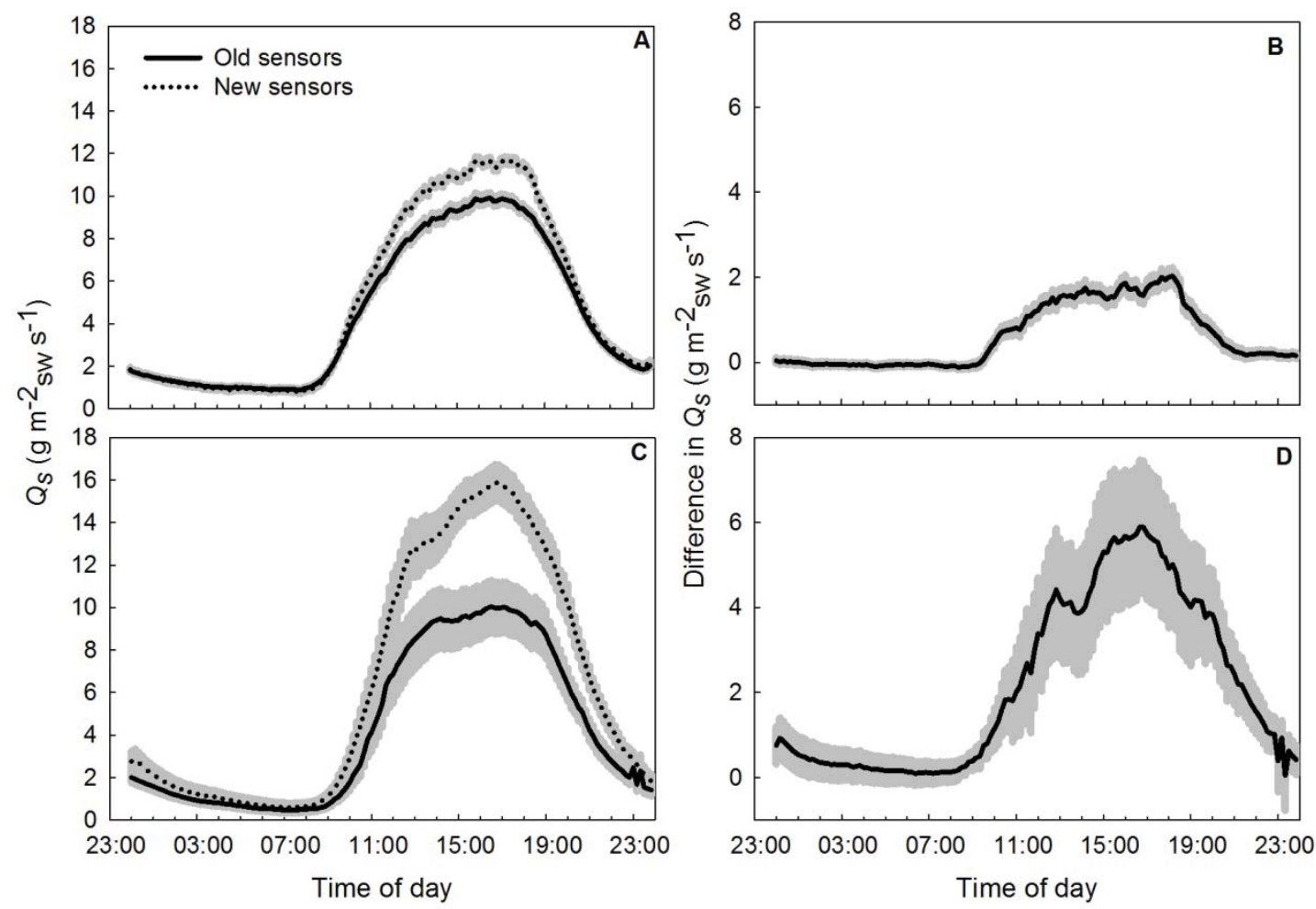

Figure 4.1. a) Sugar maple sap flux density per unit sapwood area $\left(\mathrm{Q}_{\mathrm{s}}\right)$ of three and one year old probes, b) mean difference in sugar maple sap flux density, c) trembling aspen $\mathrm{Q}_{s}$, and d) trembling aspen mean difference for the 2013 growing season (MayOctober). Grey shading indicates one standard error of the ten minute means. 


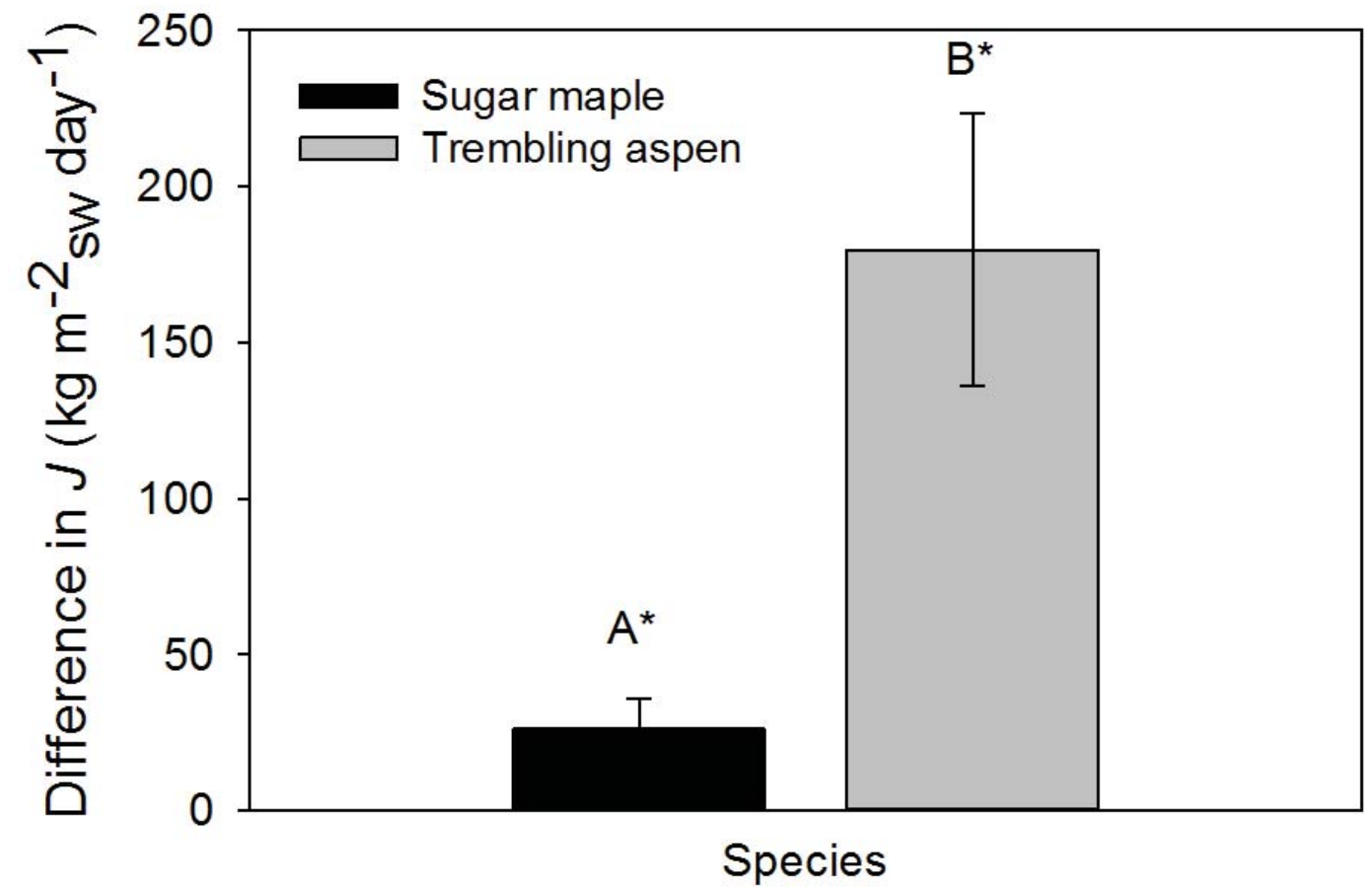

Figure 4.2. Mean difference in J between three year old and one year old sap flux probes per unit sapwood area in two hardwood species for the 2013 growing season (May-October). Bars indicate one standard error of the mean. Letters indicated significant difference between species, while asterisks indicate significant differences from zero. 


\subsection{References}

Barrett, D. J., T. J. Hatton, J. E. Ash, and M. C. Ball. 1995. Evaluation of the heat pulse velocity technique for measurement of sap flow in rain-forest and eucalypt forest species of south-eastern Australia. Plant, cell and environment 18:463-469.

Biggs, A. R. 1992. Anatomical and physiological responses of bark tissues to mechanical injury. Defense Mechanisms of Woody Plants Against Fungi:1340.

Biggs, A. R. 1997. Increased suberin accumulation in peach $\mathrm{x}$ almond hybrids. HortScience 32:717-718.

Cochard, H. and M. T. Tyree. 1990. Xylem dysfunction in quercus - vessel sizes, tyloses, caviation and seasonal-changes in embolism. Tree Physiology 6:393407.

Copini, P., J. den Ouden, and M. Decuyper. 2014. Early wound reactions of Japanese maple during winter dormancy: the effect of two contrasting temperature regimes. AOB Plants 6.

Crane, P. E., Y. Hiratsuka, and P. V. Blenis. 1995. Black stem galls on aspen anotomy and histochemistry. Canadian Journal of Botany 73:391-412.

David, T. S., M. I. Ferreira, S. Cohen, J. S. Pereira, and J. S. David. 2004. Constraints on transpiration from an evergreen oak tree in southern Portugal. Agricultural and forest meteorology 122:193-205. 
Frankenstein, C., U. Schmitt, and G. Koch. 2006. Topochemical studies on modified lignin distribution in the xylem of poplar (Populus spp.) after wounding. Annals of Botany 97:195-204.

Gebauer, T., V. Horna, and C. Leuschner. 2008. Variability in radial sap flux density patterns and sapwood area among seven co-occurring temperate broad-leaved tree species. Tree Physiology 28:1821-1830.

Granier, A. 1985. A new method of sap flow measurement in tree stems. Annales des sciences forestières 42:193-200.

Granier, A. 1987. Evaluation of transpiration in a douglas-fir stand by means of sap flow measurements. Tree Physiology 3:309-319.

James, S. A., M. J. Clearwater, F. C. Meinzer, and G. Goldstein. 2002. Heat dissipation sensors of variable length for the measurement of sap flow in trees with deep sapwood. Tree Physiology 22:277-283.

Jarvi, M. P. and A. J. Burton. 2013. Acclimation and soil moisture constrain sugar maple root respiration in experimentally warmed soil. Tree Physiology 33:949-959.

Lu, P., L. Urban, and P. Zhao. 2004. Granier's thermal dissipation probe (TDP) method for measuring sap flow in trees: Theory and practice. Acta Botanica Sinica 46:631-646.

Moore, G., B. Bond, J. Jones, and F. Meinzer. 2010. Thermal-dissipation sap flow sensors may not yield consistent sap-flux estimates over multiple years. Trees 24:165-174. 
Schmitt, U. and W. Liese. 1993. Response of xylem parenchyma by suberization in some hardwoods after mechanical injury. Trees-Structure and Function 8:2330.

Sebestyen, S. D., C. Dorrance, D. M. Olson, E. S. Verry, R. K. Kolka, A. E. Elling, and R. Kyllander, editors. 2011. Long-term monitoring sites and trends at the Marcell Experimental Forest. Chapter 2. CRC Press, Boca Raton, FL.

Steppe, K., T. Doody, and R. Teskey. 2010. A comparison of sap flux density using thermal dissipation, heat pulse velocity and heat field deformation methods. Agricultural and forest meteorology 150:1046-1056.

Sun, Q., T. Rost, and M. Matthews. 2008. Wound-induced vascular occlusions in Vitis vinifera (Vitaceae): Tyloses in summer and gels in winter1. American journal of botany 95:1498-1505.

Swanson, R. H. and D. W. A. Whitfield. 1981. A numerical-analysis of heat pulse velocity theory and practice. Journal of experimental botany 32:221-239.

Tang, J., P. Bolstad, B. Ewers, A. Desai, and K. Davis. 2006. Sap flux-upscaled canopy transpiration, stomatal conductance, and water use efficiency in an old growth forest in the Great Lakes region of the United States. Journal of geophysical research 111.

Urbanus, S. L. and T. Ott. 2012. Plasticity of plasma membrane compartmentalization during plant immune responses. Frontiers in Plant Science 3:181. 
Wullschleger, S., K. Childs, A. King, and P. Hanson. 2011. A model of heat transfer in sapwood and implications for sap flux density measurements using thermal dissipation probes. Tree Physiology 31:669-679.

Zhao, X. H. 2014. Development of tyloses in the xylem vessels of Meili grapevine and their effect on water transportation. Russian journal of plant physiology 61:194-203. 


\section{Conclusions}

Overall, this dissertation came to several conclusions across each study. First, sugar maple productivity could potentially decrease due to warming-induced drought within its current range, especially on drier sties. Canopy warming research needs to be investigated to calculate if further decreases of transpiration will occur as it did with our soil warming experiment. Second, trembling aspen may not be as affected by climate change in northern Minnesota as much as in its southern species range. Our correlations with volumetric soil water content with trembling aspen could indicate a larger sensitivity to soil water than red maple. Red maple would be able to use excess available soil moisture, unused by decreasing trembling aspen, and increase within its suitable range within the forests in the Midwestern United States. Lastly, sap flux sensors have been found to underestimate the rates of transpiration due to wounding effects. Future sap flux researchers need to be aware of the inevitable loss of accuracy in sensor data due to wounding effects and work to find an adjustment ratio to compensate for the underestimated data. Overall, this study as a whole found that climate change is going to affect many tree species across the Midwestern United States. Collaboration with forest managers, government, and the general public needs to take place with climate scientists to ensure that key tree species are not severely affected by human induced climate change. 